\title{
Goran Filipi \\ ETIMOLOGIJSKA OBRADBA \\ ISTRORUMUNJSKOGA LEKSIKA \\ KOJI SE TIČE VOĆKI
}

\author{
Izvorni znanstveni rad \\ Original scientific paper
}

UDK 811.135.1'282'373.22:634.1.055>(497.5-3 Istra)

U članku se raspravlja o istrorumunjskim nazivima koji su u bilo kakvoj svezi s voćkama. Obrađeni su oblici dio opsežnijega korpusa od preko 8000 oblika koji smo sami prikupili (istraživanja su obavljana u više navrata od 1985. godine posljednje provjere i dopune korpusa obavljene su tekuće, 2011., godine i to u svim mjestima gdje se i danas govori istrorumunjski: Žejane, Šušnjevica, Nova Vas, Jesenovik, Letaj, Brdo, Škabići, Trkovci, Zankovci, Miheli, Kostrčan). Uz svaku obrađenu riječ navode se odgovarajuće iz svih dostupnih nam istrorumunjskih repertoara. Za svaku riječ daje se etimologijsko tumačenje do kojeg se dolazi usporedbom pojedinog termina s odgovarajućim čakavskim i istromletačkim okolnim govorima, a ako je riječ domaća, daju se i paralele iz ostala tri rumunjska dijalekta. U obrađenoj građi prevladavaju posuđenice iz čakavskih govora. Domaće su riječi malobrojne. Izravnih posuđenica iz (istro)mletačkoga nema.

Ključne riječi: istrorumunjski, rumunjski, hrvatski, čakavski, dijalektologija, etimologija

\section{Grafija i kratice}

Za istrorumunjske oblike koje smo sami zabilježili služimo se grafijom koju smo sastavili za IrLA. Riječ je o prilagođenoj hrvatskoj latinici kojoj su dodani grafemi koji izražavaju istrorumunjske posebne glasove i posebni znakovi za digrame lj i nj:

å - stražnje muklo $a$

$\varepsilon$-jako otvoreno $e$

ə - poluglas, čuje se između vi r u hrvatskoj riječi vrt - odgovara rumunjskome $\breve{a}$

"c-jako umekšano č

ś - umekšano š

ź - umekšano ž

3- početni glas u tal. zelo

$\breve{g}$ - glas između hrvatskoga dž i đ

y-velarni zvučni frikativ, kao u španjolskom lago

Í- hrvatsko lj

ń - hrvatsko $n j$

Naglasak u ir. riječima bilježimo podcrtavanjem naglašenoga vokala, osim å koje je uvijek naglašeno. U jednosložnim riječima naglasak se ne bilježi.

Ir. imenice navode se u jednini bez člana, čemu slijede nastavci za određeni član (-u ili - $a$ ), za množinu $(-\varnothing,-e,-\check{c}, \ldots)$, za množinu s određenim članom (-i, -ele,...) i na kraju odrednica roda ( $m$., ž. ili bg.). Uz infinitiv glagola daje se u zagradi oblik za 1. I. jd. prezenta. 
Čakavske, slovenskoistarske i istromletačke oblike koje smo sami prikupili pišemo istom grafijom, a naglasak na prvima bilježimo kako je to uobičajeno u hrvatskoj odnosno slovenskoj, dijalektološkoj literaturi, dok za istromletačke naglasak bilježimo podcrtavanjem naglašenoga vokala. Oblike iz literature vjerno prenosimo prema izvorniku.

U radu smo se služili sljedećim kraticama:

ar. - arumunjski

arap. - arapski

bilj. - bilješka

bg. - srednji rod rumunjskoga tipa

coll. - zbirna imenica

čak. - čakavski

češ. - češki

dr. - dačkorumunjski

germ. - germanski

furl. - furlanski

grč. - grčki

hrv. - hrvatski

imlet. - istromletački

ir. - istrorumunjski

jd. - jednina

juž. s. - južna sela (Šušnjevica, Nova Vas, Jesenovik, Letaj, Brdo, Škabići, Trkovci, Zankovci, Miheli, Kostrčan)

kas. - kasno

knjiž. - književni

I. - lice

lat. - latinski

m. - muški rod

mak. - makedonski

mlet. - mletački

mn. - množina

mr. - meglenorumunjski

n. - srednji rod hrvatskoga tipa

neodr. - neodređeni

njem. - njemački

OA - osobne ankete

odr. - određeni

prslav. - praslavenski

prid. - pridjev

reg. - regionalno

rum. - rumunjski

rus. - ruski

sln. - slovenski

st. - staro

stsl. - staroslavenski

šp. - španjolski

tršć. - tršćanski

usp. - usporedi

V. - vidi

vlat. - vulgarnolatinski

ž. - ženski rod 


\section{Jabuka (Malus domestica) - stablo i plod}

U svim istrorumunjskim selima naziv za stablo jednak je nazivu za plod. U Žejanama mer, -u, merre, -ele m., u Šušnjevici, Brdu i Škabićima mer, -u, mere, -ele bg., u ostalim južnim selima mer, $-u$, mer, $-i$. U Jesenoviku su nam dali i termin za divlju jabuku: jabučcić, $-u,-i,-i$.

Oblici tipa mer domaći su: Maiorescu navodi mer i măr (potonje uz naznaku rjeđe) kao dvije natuknice, prvu za plod, drugu za stablo - razlikuju se po mn. obliku: za plod mere, za stablo meri (VIrR 112), Byhan i za plod i za stablo mer, -u, -ri, -rurle (IrG 274), Popovici i za plod i za stablo mer, $-u,-i$ (DRI 124), Cantemir mer, -r (TiR 171), Sârbu i Fraţila i za plod i za stablo mer, mn. mer (DIr 227), Kovačec i za plod i za stablo mer, -u, mẹ́re, -ele (IrHR 115) < lat. malum, REW 5272.1 > dr. u Rudnoj Glavi mlar (stablo), mara (plod) (IrLA 1617), măr, mn. meri (stablo), măr, mn. mere (plod) (DEX 608), mer (DRI 124, s. v. mer); ar. mer, mn. merĭ, măr (stablo), mer, mn. meáre, măr (DDAr 678), mer, mn. meri (stablo), mer, mn. meari (plod) (DArM 339), mert, mn. meri (stablo), meru, mn. meáre (plod) (ADK 235); mr. mer (stablo), meára (plod) (DMr 187, 188).

Naziv za divlju jabuku (Malus silvestris), jabučićposuđen je iz nekog čakavskog govora: npr. na Boljunštini, na Grobinštini, u Rukavcu kod Senja jäbučić (RBG; GG 284)1 - umanjenice na dvojni deminutivni sufiks -čić od jabuka: npr. u Labinu jābuka (RLC 110), u Funtani jàbuka (MFR 35), u Brgudu i Čepiću; Orbanićima kod Žminja; u Medulinu; na Grobinštini; u Senju; na Braču jäbuka (IILA 1617; ČDO 456; RMG 89; GG 284; SR 47; RBČG 347) < prslav. *äb/ıka (HER 284).

\section{1. (O)guliti (o jabuci, kruški i sl.)}

U Šušnjevici (o)ĺupị (jo (o)lupeśs), u svim ostalim selima (o)ĺupị (jo (o)lupẹs).

Od autora istrorumunjskih repertoara kojima se služimo samo Dianich ima o-lju'pi (VIrl 137) i lju'pi (VIrl 124). Glagol je posuđen iz nekog čakavskog idioma: npr. u Brgudu olüpit, u Čepiću olupït (IrLA 1616), u Vodicama lûpiti (ID 189, s. v. l̦upìna), u Orbanićima kod Žminja lüpït, ulüpït (ČDO 484), u Boljunu lūpït, olüpït (RBG), u Labinu i Pićnu lupit (RLC 147; PI 60), olupit (RLC 183; PI 76), u Funtani lûpiti (MFR 46), u Belom na Cresu lupitt (BBT 207), olupït (BBT 277), u Rukavcu i Crikvenici lüpït (RČGR 144; CB 57), olüpït (RČGR 189) < prslaven. *o (SES 390) + *lupiti (SES 313).

\subsection{Ogrizak jabuke}

U Žejanama yriža (yriža, - $a$, -e. -ele ž.) de mer, u Šušnjevici i Novoj Vasi oglobine, -a, -e, -ele ž., u Jesenoviku i Brdu oglobina, -a, -e, -ele ž., u Škabićima, Trkovcima i Kostrčanu poglogdak, poglodaku, poglodki/poglodąki, poglodki/poglodaki m., u Letaju, Zankovcima i Mihelima uosu de mer.

Ni jedan navedeni termin ne nalazimo u autora istrorumunsjkih repertoara kojima se služimo.

Žejanski je naziv čakavizam: potvrdu nalazimo samo za Grobinštinu, griža (GG 268)². U osnovi je riječi glagol tipa gristi: npr. u Boljunu grìs (RBG), u Orlecu na Cresu grĩst (ČDOC 248), na Grobinštini, u Senju grìst (GG 268, SR 36) < prslav. * ${ }^{*} r y z t i($ (SES 158).

Nazivi tipa oglobina također su čakavskog podrijetla. Potvrdu imamo samo za Čepić: og/öbina (IrLA 1618). Etimologija nije najjasnija. Tomo Maretić uz og/obina piše: "ostaci onoga, što je oglodano, upravo oglobleno, ali glagolu oglobiti nema potvrde za značeńe koje bi odgovaralo." (ARJ VII/748). Čini se da je u osnovi naše tvorenice s o- glagol gläbati uz koji Skok piše: "'sinonim: glodati"3 = sa o umjesto a globäti, g/öbljem (ŽK) (o-) "nagen (sc. glodati)" i slov. glóbati, glóbljem

Oblikjäbučić ima i Janeke Kalsbeek, ali u značenju "ciklama" (ČDO 456).

U istom značenju i griža (ARI III/439).

Glagol stoji i u ARJ III/140 (taj je dio obradio P. Budmani) uz napomenu: "Može biti da korijen glab postaje 
"1 dupsti, $2^{\circ}$ glodati"04 (...) Prema tome je a prijevoj od o (...)" (SKOK I/563). Što se praslavenskog etimona tiče ne daju ga izrijekom ni Skok ${ }^{5}$ ni Bezlaj. Obojica pretpostavljaju vezu sa žlijeb, odnosno sln. žleb. Uz žlẹb Marko Snoj piše: "Pslovan. *želbъ s prvotnim pomenom *'kar je izdolbeno' se je razvilo iz ide. * gelbho-, izpeljanke iz baze * gelebh- 'rezati, dolbsti, izvotliti, poglabljati' (SES 764). Snoj žleb dovodi u svezu s globök (SES 144), a ovo s glódati uz koje daje praslavenski etimon * glodati (SES 144) koji je i ishodište čakavizama tipa pog/odək. Potvrdu nalazimo samo za Medulin, pog/ödak "ostatak nepojedene hrane" (RMG 179), od glagola tipa (o)g/odati6, (po)g/odati: npr. u Labinu oglodàt (RLC 182), na Boljunštini og/odät (RBG), na Grobinštini glodät (GG 260), og/odät (GG 434), poglodät (GG 487), na Braču glodät (RBČG 251).

Sintagma "osu de mer sastavljena je od domaćih elemenata, doslovce znači "kost od jabuke". Prvi dio osu predstavlja imenicu "kost" s određenim članom: u Žejanama smo zabilježili os, $-\boldsymbol{u}, \boldsymbol{-} \boldsymbol{e}$, -ele, m., u Šušnjevici, Jesenoviku, Letaju, Brdu, Trkovcima, Zankovcima, Mihelima i Kostrčanu os, - u, -e, -ele bg, u Mihelima i uos, -u, -ure, -urle bg., u Šušnjevici, Novoj Vasi i Škabićima os, -u, -ure, -urle bg - u istrorumunjskim repertoarima kojima se služimo nalazimo os, - $u$ mn. ose, osele (DRI 132), os, mn. osă (VIr 137), os (uos), -e DIr 244), os, -u, óse, -ele za Žejane, Šušnjevicu i Novu Vas i os, -u, -ure, -urle za Šušnjevicu (IrHR 138)] < lat. ǒssum, REW 6114 > dr., ar. os (DEX 731, DDAr 809), mr. uos (DMr 316). Drugi dio sintagme također je domaći: u svim smo mjestima zapisali de [de (VIr 103; IrG 204; DRI 106; SIr 308; TIr 164; DIr 205; IrHR 66)] < lat. de, REW 2488 > dr. de (DEX 262); ar. di (DDAr 382; DArM 191); mr. di (DMr 107). Za merv. 1.

\section{3. (S)tresti (o jabuci)}

U Šušnjevici (s)tresi (jo (s)treséśk), u svim ostalim selima (s)tresi (jo (s)tresess).

Byhan, Puşcariu i Cantemir imaju stresí (IrG 353; SIr 326; TIr 181) i tresí (IrG 363; SIr 327; TIr 183), Popovici stresi (DRI 152) i tresi (DRI 159), Sârbu i Fraţila streşi (DIr 280), Kovačec za Žejane stresí (IrHR 184) i tresí se (IrHR 199). Preuzeto iz nekog čakavskog govora: npr. u Brgudu (s)trêst, u Čepiću três (IrLA 1619), u Svetvinčentu i Ližnjanu trêsti (ILA 1619), na Boljunštini trĩes (RBG), u Orlecu na Cresu trẽst (ČDOC 382), na Grobinštini strêst (se) (GG 614) i trêst (GG 666), u Senju strẽst (se) (SR 138) i trẽst (SR 154), na Braču strẹst (RBČG 895) i trẹst (RBČG 970) < prslav. (*s6) (SES 550) + *tręsti (SES 681).

\section{Kruška (Pyrrus communis) - stablo i plod}

I za stablo i za plod u Žejanama i Jesenoviku smo zapisali $\boldsymbol{h} r \underline{u s ̌ v a},-\boldsymbol{a},-\boldsymbol{e}$, -ele ž., u Žejanama i hrušsva, - $a,-i$, -ile ž., u Šušnjevici hrusve, - $a$, -i, -ile ž., frusve, - $a$, -i, -ile ž. i pere, - $a,-e$, -ele ž., u Novoj Vasi $h r \underline{u s ̌ v \varepsilon, ~}-a$, -i, -ile ž., hrušve, - $a$, -e, -ele ž. i pere, - $a$, -i, -ile ž., u Brdu per, -u, perre, -ele bg., u ostalim mjestima per, -u, per, -i m., u Letaju i pera, - $\boldsymbol{a}$, - e, -ele ž. i frušva, - $\boldsymbol{a}$, -e, -ele ž. U Letaju smo dobili i termin za divlju krušku (Pyrus amygdaliformis): frušvič, - $-\boldsymbol{u},-\boldsymbol{\emptyset}$. - $\boldsymbol{i}$ m.

Nazivi tipa f(h)rušva posuđeni su iz nekog sjevernočakavskog idioma7: npr. u Brgudu hrüšva, u Čepiću früšva (IrLA 1620), u Pićnu hrüšva (PI 41), u Orbanićima kod Žminja i na Grobinštini hrüšva

ojačańem od korijena glob glagola razg/obiti, kod kojega bi se shvatilo da je značenje korijena onakovo kao što je cijelome složenom glagolu."

Pleteršnik ima glóbati (MtP-cd), a Bezlaj uz glóbsti "dolbsti (sc. dubiti)" piše: "tudi glóbati, glóbam, glóbljem "doIbsti, izpodjedati" (pkm.), "gristi" (bkr.), izglóbati "izdolbsti", preg/óbati "pregristi, prevrtati", globûra "oglodana kost" (...)" (ESSJ I/148).

5 Skok kao ishodište daje indoevropski korijen * gelebh- "schaben, schabend aushöhlen" (SKOK, loc. cit.).

6 > u Šušnjevici oglodi (jo oglodeśk), u ostalim mjestima oglodi (jo oglodess) - Cantemir navodi oglodí (TIr 173), Kovačec za Žejane oglodí (IrHr 136).

"hrüšva (sthrv., sjeverni čakavci)" (SKOK II/215, s. v. krüška). Južno oblici tipa kruška, kao u hrvatskom standardu: krüška (RHJ 512) < prslav. *kruša (SES 178). 
(ČDO 454; GG 279), na Boljunštini hrüšfa (RBG). Naziv za divlju krušku, frušvič, umanjenica je na -ič od navedenih naziva: na Grobinštini hrüšvić "divlja kruška sitnih plodova" (GG 279), hrûšfić "divlja kruška" (RBG). Byhan navodi frúŝvę (IrG 220) i hrúŝvę (IrG 230), Popovici hruşva za plod (DRI 115), Popovici fruşva, -ile za plod (DRI 135, s. v. pęres), Cantemir za stablo i plod hrúşve (TIr 168), Sârbu i Fraţilă hruşva (DIr 217), Kovačec za stablo i plod hrúşvę za Šušnjevicu i hrúşva za Žejane (IrHR 91).

Nazivi tipa per domaćeg su podrijetla: Maiorescu donosi per i pĕr, mn. pere za plod i per, mn. peri za stablo (VIrR 116), Byhan per, -ri za stablo i pere, -re za plod (IrG 305), Popovici per, -u, mn. -i za stablo8 i pęre (DRI 135), Cantemir za plod pére (TIr 175), Sârbu i Fraţilă per za stablo i pęra za plod (DIr 249), Kovačec za Brdo per za stablo i plod (IrHR 145) < lat. pĭrus, REW 652510 > dr. u Rudnoj Glavi pząr za stablo i pjára za plod (IrLA 1620), păr (DEX 764) - páră (DEX 751); ar. per (DDAr 837) - peáră (DDAr 836); mr. per - peáră (DMr 219).

\subsection{Gnjila kruška}

U Žejanama smo dobili odgovor yńila hruš̌va, u Šušnjevici gńịle hrusve, u Novoj Vasi gńịla hrušve, u Jesenoviku gńila hrưšva, u ostalim južnim selima gńi per, u Mihelima i peru gńi.

Za per i hrušva v. 2. U ovom ćemo odjeljku obraditi pridjev "gnjio, gnjila, gnjilo". U Žejanama smo yńiju, yńila, yńilo; yńili, yńille, yńili, u Šušnjevici i Novoj Vasi gńivu, gńile, gńilo; gńili/gńivi, gńile, gńili/gńivi, u Brdu i Trkovcima gńivu, gńila, gńilo; gńili/gńivi, gńile, gńili/gńivi, u Zankovcima, Mihelima i Kostrčanu gńi, gńila, gńilo; gńili, gńile, gńili, u Jesenoviku, Letaju i Škabićima gńil, gńila, gńilo; gńili, gńile, gńili. Byhan navodi gnil, gnyi(v)u, gnyilę (IrG 223), Popovici gńivu, gńilę (DRI 112), ostali nemaju. Posuđeno iz nekog čakavskog govora: npr. u Brgudu gńîla hrüšva, u Čepiću gniila früšva (IrLA 1621), u Svetvinčentu gńila krûška, u Čabrunićima, Valturi i Ližnjanu gńîla krüška (ILA 1621), u Medulinu gnjīja, -la, -lo (RMG 71), u Funtani gnijja, gnjîla, gnjîlo (MFR 31), u Pićnu gnjilo (PI 36), u Orbanićima kod Žminja gnjīl (ČDO 446), na Boljunštini gnjîl (RBG), na Grobinštini, u Rukavcu i Senju gnjîl, gnjīlä, gnjīlo (GG 260; RČGR 82; SR 35), na Braču gniil, gniilä, gniîlo (RBČG 253) - od gl. tipa gńijat(i) < prslav. * gniti (SES 146, s. v. gníti).- glagol su posudili i Istrorumunnji: u Žejanama smo zapisali yńili (jo yńiles), u Šušnjevici gńilẹj (jo gńilesk), u ostalim južnim selima gńilęj (jo gńiles). Navedene glagole ne nalazimo u istrorumunjskim repertoarima kojima se služimo. Oba su tipa glagola posuđena iz nekog čakavskog idioma: npr. u Pićnu gnjilit(PI 36), u Čepiću kören gniilli, u Brgudu körjeńe gniije, (IrLA 1722), u Svetvinčentu, Čabrunićima i Ližnjanu gńijäti (ILA 1722), u Medulinu također (OA), u Valturi gńijät(ILA 1722), u Senju gnjīitt(SR 35), na otoku Murteru gnjijäti (RGOM 92).

\subsection{Crv u kruški}

U Žejanama yĺermu an hrušva, u Šušnjevici ĺermu an hrusve, u Novoj Vasi jermu an hrušve, u ostalim južnim selima lérmu an per ${ }^{11}$.

Za hrušva i perv. 2. Ostaje nam obraditi imenicu (y)lerm "crv" i prijedlog an "u; na".

U svim smo mjestima zapisali an: Popovici i Cantemir imaju ăn (DRIS 145; TIr 158), Puşcariu (ă)n (SIr 303), Sârbu i Fraţilă ân (DIr 188), potonje i Kovačec (IrHR 2912) < lat. ĭn, REW 4328 > dr. în (DEX 519); ar. în (DDAr 585), ãn (DArM 73); mr. ăn (MrA 255).

Za "crv" smo u Žejanama zapisali yĺermu, -u, yĺermure, -urle m., u svim južnim selima ĺerm,

8 "se zice şi debla de fruşvi" (DRI, loc. cit.).

9 Potaknuti podatcima iz navedene literature da Istrorumunji izrijekom razlikuju kruškino stablo od ploda, nedavno smo obavili opsežnije provjere na terenu i možemo sa sigurnošću ustvrditi da danas to nije tako i da su oblici u m. r. nekada označavali stablo.

10 Za ž. r. lat. *pira (EWRS-LE 1264).

11 U Rudnoj Glavi vjarmje-n pạrz (IrLA 1622)

12 Uz inačice $\hat{a} \eta, \hat{a} m,-n,-\eta,-m, \hat{a}$ za Žejane. 


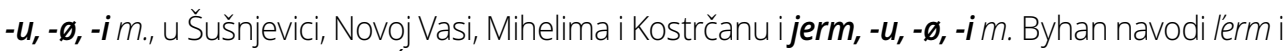
jérm (IrG 270; 233), Popovici lerm, -u (DRI 122), Cantemir lerm, -i (TIr 169), Maiorescu ierm, ierme, gherm, gherme (DIr 128), Kovačec ylérmu (rijetko ylerm, -u), mn. ylérmure, -urle i ylérmi za Žejane (IrHR 84), lérmu, lérmi za Šušnjevicu i Novu Vas i jérmu za Novu Vas u starijih govornika (IrHR109) - sve "crv". Domaća riječ: dr. viérme (DEX 1161); ar. yérmu (DDAr 9243); mr. ǵármi (MrA 115) < lat. vĕrmis, REW 9231; DER 9243.

\section{Trešnja (Prunus avium) - stablo i plod}

I za stablo i za plod u Žejanama čirišńna, - $\boldsymbol{a}$, -e, -ele ž., u Šušnjevici cirisńc, - $\boldsymbol{a}$, cirisńi, -ile ž., u Novoj Vasi čirišńn, - $\boldsymbol{a}$, čirišńi, -ile ž. i čirišńn, $-\boldsymbol{a}$, čirišńe, -ele ž., u Jesenoviku, Zankovcima, Mihelima i Kostrčanu čirišńe, - $\boldsymbol{a}$, čiriššni, -ile ž., u Zankovcima i čirišńne, - $\boldsymbol{a}$, čirišńne, -ele ž., potonje i u preostalim južnim selima.

Maiorescu ima cerisne (VIrR 99), Byhan tŝrî̌ńe (IrG 369), Popovici ćirişńa i ćireşńa (DRI 106), Sârbu i Fraţilă čereşńa i čerişńa (DIr 204), Kovačec za Novu Vas čiríşńe (IrHR 63). Posuđeno iz nekog čakavskog govora: npr. u Brgudu črěšńa, u Čepiću čerǐšńa (IrLA 1623), potonje i u Svetvinčentu, Valturi i Ližnjanu (ILA 1623), u Čabrunićima čərǐ̌ńa (ILA 1623), u Medulinu čerǐ̌nja (RMG 38), u Orbanićima kod Žminja čerëšnja (ČDO 428), na Roveriji čerišnja (RR), u Crnom na Labinštini čirešnja (HBI 136) u Srbinjaku (Jakovci, Tinjan) u Istri čerisnja, u jugoistočnoj, južnoj, srednjoj i sjeverozapadnoj Istri čerišnja (HBI 127) < prslav. *čers'bn'a (SES 71, s. v. ćệšnja). Tip če(i)ri(e)šnja, barem prema našim spoznajama, nije poznat južnije od Istre13, pa pretpostavljamo da su ga Istrorumunji preuzeli tek nakon preseljenja iz Cetinske krajine.14

\subsection{Divlja trešnja (Prunus cerasus avium)}

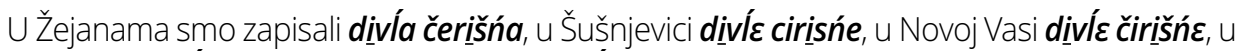
Letaju čirišńa divía, u ostalim južnim selima divía čirišńe

Autori istrorumunjskih repertoara kojima se služimo nemaju ovaj fitonim. Posuđeno iz nekog čakavskog govora: npr. u Čepiću divla čerǐšńa (IrLA 1627), u Svetvinčentu i Valturi dibla čerišńa, u Čabrunićima dỉbla čarišńa, u Ližnjanu dìmńa čerǐšńa (ILA 1628), u Medulinu dìmla čerǐšńa (OA). Ir. termini sastavljeni su od dva strana elementa, pridjeva tipa divfi "divlji" [u Šušnjevici i Novoj Vasi

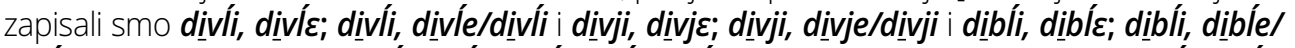

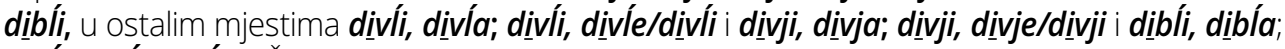
dịblí, dịble/dịbli, u Škabićima još i dịmńi, dịmńa; dịmńi, dịmńe/dịmńi - u Kovačeca nalazimo dívii (dívlii), dívia (dív'ée), dívii (dívlï) za Žejane i dívlï, dívlę, dívlì za Šušnjevicu (IrHR 69), u ostalih divl' (SIr 309); dívli, - e (TIr 164); divli (DIr 207) < čak. divji, divli < prslav. *divъ (SES 94, 95)] i imenice tipa čerišńa (v. 3.).

\footnotetext{
13 Samo tip črišńa: npr. u Rivnju črǐ̌nńa (RRG 71), u Kukljici črî̌nja (RGK 44).

14 Slavenski etimolozi pretpostavljaju latinsko podrijetlo voćke o kojoj raspravljamo što M. Snoj sažima kao: "Pslovan. * čers'sn'a je nastalo (analogno po višsn'a višnja') iz *čers'a (ohranjeno npr. v cslovan. črěša 'češnja'), kar je v 3.-4. stol. izposojeno iz vlat. ceresia (klas. lat. cerasus 'češnjevo drevo', cerasum 'češnjev plod')." (SES, loc. cit.). Lat. cerěsea, REW 1823.b dalo je i dr. cireáşă (DEX 179); mr. tšireáşă, tšireáşcă (DMr 98); ar. tseriašă, tsirešiu (EWRS-LE 338) - Puşcariu oba oblika navodi prema Densusianuu i uz oba stavlja znak pitanja, dok Cioranescu prvi Densianuov oblik navodi bez dvojbi, ţeriaşă (DER 2021) - valja reći da sličnih riječi nema ni u DDAr, ni u DArM, ni u ADK. Sigurni smo da su Istrorumunji prije prelaska Dunava u svom leksiku imali neku riječ za trešnju sličnu ovima u drugim rum. dijalektima ali su ga s vremenom prilagodili hrvatskim terminima. Ako u če-, či- želimo vidjeti ostatak nekog izgubljenog prvotnog oblika, trebali bismo gore navedene hrvatske nazive za trešnju držati prilagođenicama prema istrorumunjskome. Bilo kako bilo i Puşcariu (EWRS-LE, loc. cit.) ir. termin tumači kao hrvatski: "(ir. tŝiriŝńe < kroat. tšerešnja)"
} 


\subsection{Rašeljka (Prunus mahaleb)} 3.1.).

U Žejanama ursuluj čirišńe, a u južnim selima nazivi su jednaki nazivima za divlju trešnju (v.

Prvi je elemenat žejanske sintagme ursuluj čirišńe (doslovce "medvjedova trešnja"15) domaći, drugi, čirišńe (v. 3.), posuđen je iz čakavskog. Urrsuluj je genitiv od unrs "medvjed"16: urs, -u, -urš/urs, -i m i ursu, -u, urš/urs, -i m. - urs (VIr 155; DRI 162; IrG 376; DER 9093), úrsu (IrHR 208 - za Žejane) < lat. ürsus, REW 9089, DER 9093 > dr. urs (DEX 1140), ar. úrsu (DDAr 1093), mr. urs (DER 9093).

\subsection{Trešnjina peteljka}

U Žejanama su nam rekli koda, - $\boldsymbol{a}$, - e, -ele ž., u Šušnjevici kod $\varepsilon_{\text {, }}-\boldsymbol{a}$, - e, -ele ž., u Novoj Vasi

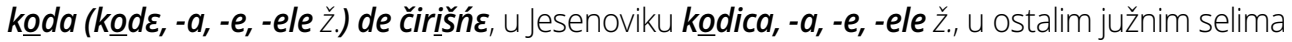
koda (koda, -a, -e, -ele ž.) de čirišńe. U Novoj Vasi smo dobili i zraz za grozd trešanja: grozdịču de čirišńc.

Nazivi za trešnjinu peteljku metaforični su, sastoje se od koda "rep"17 i, neobvezatno, de čirišńe "od trešnje" (za de v. 1.2., za čirišńe 3.). Nazivi za rep domaći su: Maiorescu bilježi codă (VIrR 100), Byhan kódę (IrG 243), Popovici codę (DRI 99), Puşcariu codę (SIr 306), Cantemir code (TIr 162), Sârbu i Fraţilă coda (DIr 198), Kovačec códę za Šušnjevicu i códa za Žejane (IrHR 51) < lat. cauda, REW 1774.1 > dr. coádă (DEX 189), u Rudnoj Glavi kuada (IrLA 1626); ar. coádă (DDAr 299), coadã (DArM 134), koáda (ADK 227), coadâ (DAr 267); mr. coádă (DMr 73). Usp. u Brgudu rêp od črěšńe (IrLA 1626), u Valturi rêp od čerǐšńe (ILA 1626).

Novovaška sintagma grozdiču de čirišńe doslovce znači "grozdić od trešnje". Prvi je elemenat hibridna izvedenica na -ič s određenim članom od grozd: u Žejanama smo zabilježili yrozd, yrozdu, yrozdi, yrozdi m., u Novoj Vasi i Škabićima grozd, grozdu, -ure, -urle bg., u Škabićima i grozd, grozdu, grozdi, grozdi m., potonje i u preostalim južnim selima. Maiorescu ima grosdă, mn. grosde (VIrR 106), Popovici grojd (DRI 113), Sârbu i Fraţilă grozd (DIr 216), Kovačec grozd za Šušnjevicu i Brdo (IrHR 87); u Žejanama yrozdič, - u, -i, -i m., u Šušnjevici grozdic, - u, -i, -i m., u ostalim južnim selima grozdičcgrozdić, $-\boldsymbol{u},-\boldsymbol{i},-\boldsymbol{i}$ m. Posuđeno iz nekog čakavskog govora: u Brgudu grözd i grôzd (IrLA 1216), u Čabrunićima i Valturi grözd, u Svetvinčentu i Ližnjanu grôzd (ILA 1216), na Grobinštini grözd, grozdić (GG 270), u Labinu grōzd (RLC 99), u Medulinu grôzd (RMG 75), na Braču grộzd, grozdić (RBČG 270) < prslav. * grozdъ (SES 161).

\subsection{Trešnjina koštica}

U Žejanama kažu bobica, - $\boldsymbol{a}$, -e, -ele ž., u Šušnjevici pescica (pescicce, - $a$, -e, -ele ž.) de cirisńe, u Novoj Vasi peščica (peščice, - $a$, -e, -ele ž.) de čirišńe, u Mihelima i Kostrčanu pešćíca (pešćíca, - $a,-e,-e l e$ ž.) de čirišńe, u Škabićima pešćica (pešćica, - $a,-e$, -ele ž.) lu čirišńne, u Zankovcima lu čirišńe punta (punta, $-a,-e$, -ele ž.), u ostalim južnim selima peščica (peščíca, $-a,-e,-e l e$ ž.) de čirišńe.

\footnotetext{
15 Usp. sln. u Izoli medvedje hruškice mn. "plod (male crvenkasto-narančaste kuglice) jedne vrste živice koja je u Izoli česta kao obrub zelenih gradskih površina" (OA).

16 Domaća riječ koja u južnim selima više nije u uporabi. Tamo koriste samo posuđenicu iz nekog čakavskog govora tipa medvid: medvid, -u, medvizz, -i m, u Šušnjevici i Novoj Vasi još i medvid, -u, -e, -ele bg., a u Letaju još i medvid, $-u,-ø,-i \mathrm{~m}$. [Byhan navodi medvíd, -u, -di, -zi, -durle (IrG 273), Popovici medvid, -u (DRI 124), Maiorescu medved (VIr 133), Cantemir medvíd, -z (TIr 170), Kovačec medvíd, -u, medvíz, -i (IrHR 115), Radu Flora za južna sela medvíd (MALGI 71) < npr. u Brgudu mëdved (IrLA 8, 9), u Svetvinčentu, Čabrunićima, Valturi medvïd (ILA 8, 9), u Orbanićima medvët (ČDO 489), u Pićnu medvit (PI 63) < prslav. *medvědb (SES 331)]. Čakavizam, uz domaću riječ, zapisali smo i u Žejanama: medved, $-\boldsymbol{u},-\boldsymbol{\emptyset},-\boldsymbol{i} m$.

17 U Jesenoviku kodica, hibridna umanjenica na -ica.
} 
Nazivi za trešnjinu košticu, osim u Žejanama, imaju strukturu u prijevodu "koštica" + "od trešnje" (de čirišńe) ili "trešnjina" (lu18 čirišńe) + "koštica", odnosno "koštica" + "trešnjina".

Žejanski naziv bobica odgovara čakavskim oblicima tipa bobica: u našem značenju npr. u Brgudu bôbica od črěšńe (IrLA 1625), u Svetvinčentu i Čabrunićima böbitsa (ILA 1625), na Braču bộbica "koštano zrno u plodu nekih biljaka, bobulja" (RBČG 119), u Selcima bôbica (RSG 42), u značenju "zrno, boba, bobica" npr. u Medulinu i Vodicama böbica (RMG 25; ID 157), u Orbanićima i Belom bôbica (ČDO 419; RBT 45). Oblik nalazimo samo u Cantemira i Popovicia i to samo u značenju "zrno, boba, bobica": bobiţe (DRI 93), bóbiţe (TIr 159). Riječ možemo tumačiti i kao izvorni oblik: dr. bobiţă, "bobica" umanjenica od boábă "boba" (DEX 104); ar. bóbă "voćka u govoru djece" (DDAr 214), bobã "id." (DArM 105); mr. bóbeă "smrikvin plod" (DMr 42). Sve su navedene rumunjske riječi potekle od oblika tipa bob: dr., ar., mr. bob (DEX 104, DDAr 214, DMr 42) što znači i "koštica" (sic!). Bilo kako bilo, krajnji je etimon prslav. *bobъ (SES 38).

Oblka tipa peščica nemaju autori istrorumunjskih repertoara kojima se služimo. Riječ je posuđena iz nekog čakavskog govora: npr. u Pićnu pešćica (PI 82), u Labinu pešćíca (RLC 199), u Orbanićima pešĉica (ČDO 516)19. Vjerojatno iste etimologije kao i sln. pečkà, pèčka "vsako od semen jabolk, hrušk, grozdnih jagod" (SSKJ-cd), pəčkà "id." (MtP-cd) < prslav. *pъtka (SES 433). S obzirom na distribuciju riječi, Istrorumunji su je posudili tek nakon dolaska na Krk i u Istru20.

U sintagmi lu čirišńe punta koju smo zapisali u Zankovcima valja nam objasniti treći elemenat, punta "koštica". Maiorescu ima puntă (VIrR 119), Byhan púntę (IrG 323), Popovici punte (DRI 142) - svi samo u značenju "(oštar) vršak" - i mi smo zabilježili oblik u tom značenju (uz značenje "svrdlo"): u Šušnjevici i Novoj Vasi punte, $-\boldsymbol{a},-\boldsymbol{e}$, -ele ž., u svim ostalim mjestima punta, $-\boldsymbol{a},-\boldsymbol{e}$ -ele ž. Samo za ta značenja (i za "rt") nalazimo i potvrde u čakavskim idiomima: npr. na Boljunštini, Grobinštini, u Orlecu, u Senju pũnta (RBG; GG 551; ČDOC 336; SR 122), u Pićnu pùnta (PI 94), u Labinu pūnta (RLC 226), u Meudinu, na Braču, u Splitu pûnta (RMG 194; RBČG 787; StR 277) < mlet. pùnta (DDP 209) < lat. puncta(m), f. sost. di punctus, part. pass. di pungere'pungere' (DELI-cd). Do značenja "koštica" u Zankovcima su došli kalkiranjem čakavskih oblika tipa špica koji znače i "vršak, šiljak" i "koštica": npr. na Boljunštini špïca "šiljak; rt", u Senju špïca "vrh" (SR 145), u Rukavcu špïca "šiljak" (RČGR 280), u Splitu špïca "tvrda jezgra ploda; zašiljeno tanko drvce, šiljasti štap" (StR 338), u Korčuli špïca "koštica od voća" (RGGK-cd) - germanizam: Spitze "konica" (SES 643)21. Mi smo slične oblike u ir. zabilježili samo u značenju "vršak": u Šušnjevici

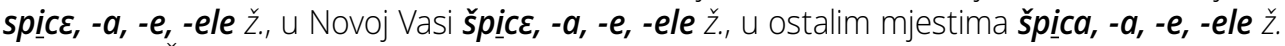
Kovačec za Žejane navodi şpiţ̧a "(oštar) vršak" (IrHR 191).22

Za de v. 1.2., za čirišńe i sl. 3.

\subsection{Trešnjina smola}

U Žejanama smola (smola, - $a$, -e, -ele ž.) de čirišńa, u Šušnjevici smola (smol $\varepsilon,-a,-e,-e l e$ ž.) de cirisńe, u Novoj Vasi smola (smolk, -a, -e, -ele ž.) de čirǐšńc, u ostalim južnim selima smola (smola, - $a,-e$, -ele ž.) de čirišńe.

Redom sintagme u doslovnom značenju "smola od trešnje". Za čirišńa i sl. v. 3., za de 1.2. Za smola samo Kovačec ima odgovarajući oblik: smólę (IrHR 178). Sličan oblik nalazimo i za dr:: smóală (DEX 997), i za ar.: smólă (DDAr 961) - i jedno i drugo u značenju "katran, paklina". Mogli

\footnotetext{
18 = čestica za tvorbu genitiva i dativa.

19 Drugo je pešćica "mala pest" (u Istri i Dalmaciji), umanjenica od pest < prslav. *pestb (SES 438).

20 I u ARJ IX/804 nalazimo potvrdu samo za sjeverne čakavske govore: u Bakru: pešĉica "koščica (u voću)".

21 > sln. špica "konica, ost" (MtP-cd); '̌spica "konica; čipka" (NSSA 124).

22 Pitanje je je li isto i spítsę "prečka (u Istri se za potporanj i prečku kaže punta - nap. autora)" (IrG 348), spiţ̧ de băt "držak čekića" (DRI 151): dr. spiţă (DEX 1010); ar. spiţ̧ă (DDAr 967); mr. spitsă "trn" (DMr 272): "Al. Spitze, por mediación del bg. sb. rus. spica 'rayo'." (DER 8086) - kao i sln. "špíca 'napera pri kolesu ali dežniku'< prslav. *stıpica 'napera, prečka, palica'." (SES 643) usp. u Izoli špica "žbica" (OA).
} 
bismo zaključiti da su Istrorumunji riječ prenijeli preko Dunava i nakon dolaska u Cetinsku krajinu ili kasnije prilagodili joj značenje prema čakavskim sličnozvučnicama: npr. u Brgudu smôla od črëšńe, u Čepiću smôla od čerišńe (IrLA 1624), u Čabrunićima smõla, u Valturi smôla ud čerišńe, u Ližnjanu smôla od čerǐšne (ILA 1624), na Grobinštini smolä (GG 597), u Medulinu smõla (RMG 215), na Braču smōlä (RBČG 875) < prslav. *smola (SES 586).

\section{Višnja (Prunus cerasus) - stablo i plod}

I za stablo i za plod u Šušnjevici vissńc, - $\boldsymbol{a},-\boldsymbol{e}$, -ele ž., u Novoj Vasi višńń, - $\boldsymbol{a},-\boldsymbol{e}$, -ele ž., u svim ostalim mjestima višńa, $-a,-e$, -ele ž.

Od istrorumunjskih repertoara kojima se služimo samo u Cantemira nalazimo vişńe (TIr 186). Istorumunjski termini odgovaraju dr., ar. i mr. nazivima za plod višnje: dr. višznə (IrLA 1630 - za Rudnu Glavu), vişină (DEX 1165); ar. vişină, vişnă (DDAr 1114); mr. vişină, vişnă (DMr 328), pa bi riječ svakako trebalo tumačiti kao izvornu, poduprtu i prilagođenu čakavskim istoznačnim sličnozvučnicama: npr. u Brgudu i Čepiću (IrLA 1630), u Svetvinčentu, Čabrunićima, Valturi i Ližnjanu (ILA 1630), na Braču (RBČG 1024) višńa, na Roveriji višnja (RR), na Grobinštini, u Medulinu, u Orbanićima vǐšnja (GG 690; RMG 256; ČDO 584) < prslav. *višbn’i (SES 720).

\section{5. Šljiva (Prunus domestica) - stablo i plod}

Istrorumunji koriste isti izraz i za stablo i za plod šljive, no imenom razlikuju šljivu koja rađa svijetle od šljive koja rađa tamne plodove. Za prvu u Žejanama vele slìva, - $\boldsymbol{a},-\boldsymbol{e}$, -ele ž., u Šušnjevici i

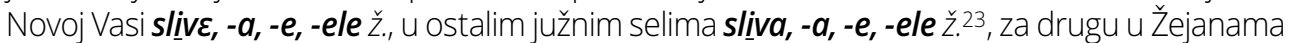
čišpa, $-a,-e$, -ele ž. i češpa, - $a$, -e, -ele ž., u Šušnjevici i Novoj Vasi $k r \underline{e} k \varepsilon,-a,-e$, -ele ž., u ostalim

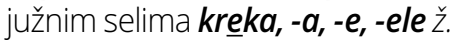

Za šljivu općenito (tip sliva) Sârbu i Fraţilă navode sliva (DIr 275), Kovačec za Žejane slíva (IrHR 178). Posuđeno iz nekog čakavskog idioma: npr. sliva u Brgudu i Čepiću (IrLA 1629), u Čabrunićima (ILA 1629), u Vodicama (ID 212), u Orbanićima (ČDO 547), na BraČu (RBČG 870), u Rivnju (RRG 272), na Boljunštini (RBG), na Grobinštini (GG 595), u Korčuli (RGGK-cd), s/ĩva u Labinu (RLC 250), sliva u Pićnu (PI 103) < prslav. *sliva (SES 581).

Za šljivu koja rađa modre24 plodove u južnim je selima u uporabi tip kreka, preuzet iz čakavskoga. Byhan i Popovici uz krékę (IrG 254), odnosno crece (DRI 102) daju općenito značenje "šljiva"25, dok Kovačec uz crékę (IrHR 55) veli "šljiva (vrsta)": u Pićnu krèka "plava šljiva" (PI 53), u Orbanićima krëka "blue plum" (ČDO 472), u Labinu krēka "šljiva" (RLC 134), u Funtani krēka "vrsta šljive" (MFR 41), na Boljunštini krëka "plava šljiva26" (RBG), na Roveriji kreka "šljiva", u Čepiću krëka "tamna šljiva" (IrLA 1629)27. Germanizam prisutan samo u istarskim čakavskimgovorima28: usp. njem. Krieche "cimbara (sc. modra šljiva)" (VNSS-cd).

Žejanski naziv čišpa posuđen je iz nekog istarskog čakavskoga govora [npr. u Brgudu čišpa (IrLA 1629)29, na Boljunštini čěšpa "plava šljiva" (RBG)] $]^{30}$ kamo je (ako nije izvorni germanizam) dospio iz slovenskoga: čéšpa (SSKJ-cd), čêšpa (MtP-cd): "Prevzeto iz nar. avstr. nem. Zweschpen,

\footnotetext{
23 Tisu termini ujedno i hiperonimi.

24 Usput: "Pslovan. *sliva je v ženskem spolu posamostaljeni pridevnik *slivъ 'moder, modrikast' (...)" (SES, loc. cit.).

25 Značenje "šljiva općenito" imamo i u Labinu i na Roveriji (v. dalje).

26 Uz napomenu: "tako se govori u p. o. Paz i u srednjoj Istri".

27 Iz čakovskoga su termin posudili i govornici istriotskog u Balama: k'reke "šljive", kre’ker "stablo šljive" (ILA 1629 - ako žele razlikovati plodove po boji, riječi za njih koriste s pridjevima: k'reke b'janke, k'reke 'negre), crèca "susina (sc. šljiva)" (DDV 35).

28 "KREKA, f. trnošliva (drvo i plod). - U naše vrijeme u Istri." (ARJ V/501). Glede distribucije v. i HBI 332, s. v. kreka.

29 Za divlju šljivu vele divla čišpa (IrLA 1758).

30 Oblik je poznat i u Gorskom kotaru: čišpa "Prunus domestica"; govori se u Liscu povrh Klane u Gorskome kotaru (HBI 136).
} 
knjiž. avstr. nem. Zwetscke, južnonem. Zwetschge 'češplja, podolgovata sliva' (...)" (SES 71, s. v. čẹ̌šplja). Od istrorumunjskih repertoara kojima se služimo samo Sârbu i Fraţilă imaju čeşpa "prune de culoare albastră (sc. modra šljiva)" (DIr 204).

\subsection{Divlja šljiva (Prunus mirabolanus)}

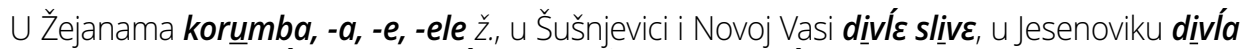
slivva, u Zankovcima divía krekea i divía sliva, u Škabićima divía krekea, u ostalim južnim selima divíe krekka.

Žejanski korumba označuje i rogač (v. 12.)31. Za sliva i kreka v. 5., za divla 3.1.

\section{Breskva (Prunus persica) - stablo i plod}

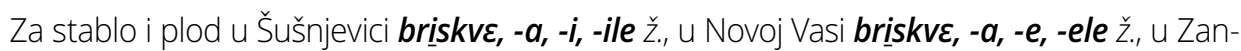
kovcima briskva, - $\boldsymbol{a},-\boldsymbol{i}$, -ile ž., u Kostrčanu briskve, $-\boldsymbol{a}$, -i, -ile ž., u svim ostalim selima $\boldsymbol{b}$ riskva, $-\boldsymbol{a}$,

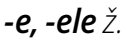

Sârbu i Fraţilă donose brescva (DIr 193), Kovačec za Šušnjevicu bríscvę (IrHR 41), ostali nemaju. Posuđeno iz nekog čakavskog govora: npr. u Brgudu brëskva, u Čepiću brïskva (IrLA 1631), u Svetvinčentu i Čabrunićima također (ILA 1631), u Vodicama brïskva (ID 159): "Slovan. *bersky je kakor srvnem. Pfersich, nem. Pfirsich 'breskev' prevzeto iz srlat. pers(i)ca 'breskev'. Lat. beseda dobesedno pomeni 'perzijska'. Breskev je namreč v Evropo prišla iz Perzije." (SES 46, s. v. brệskev).

\subsection{Breskvina koštica}

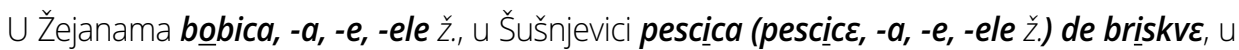
Novoj Vasi peščica (peščice, - $a$, -e, -ele ž.), u Kostrčanu peščica (peščica, -a, -e, -ele ž.) de briskve, u ostalim južnim selima peščíca (peščica, $-a,-e$, -ele ž.) de briskva.

Za bobica i peščica i sl. v. 3.4., za breskva i sl. 6., za de 1.2.

\section{Marelica (Prunus armeniaca) - stablo i plod}

I za stablo i za plod u Šušnjevici armulink $\boldsymbol{\varepsilon},-\boldsymbol{a},-\boldsymbol{e}$, -ele ž., u Jesenoviku i Letaju armulinka, - $\boldsymbol{a}$,

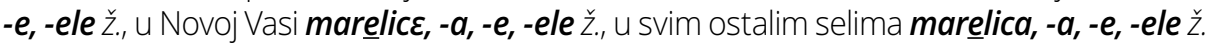

Autori istrorumunjskih repertoara kojima se služimo nemaju odgovarajućih oblika. Oba su naziva u istrorumunjske govore ušla iz čakavskoga. Prvi, armulinka, izvedenica je na -ka od posuđenica iz (istro)mletačkoga tipa armulin: npr. u Raši armulin (HBI 38), u Labinu armulīn (RLC 38), u Orbanićima armulîn (ČDO 414), u Senju armulîn (SR 2), u Splitu i Trogiru armèlīnka (StR 8; RTCG 22), u Dalmaciji armelinka (HBI 38) < armelin (BOE 44; DDP 30), armelin (VG 38), armolin (DDP 31), armelín (DDC 6)32 - "Voce veneta, dal lat. Armenius '(albero) dell'Armenia"' (DLI-cd). Drugi, marelica, mogao je ući iz kojeg čakavskog govora [npr. u Pićnu marèlica (PI 62), u Brgudu, Čepiću; Ližnjanu; Medulinu marëlica (IrLA 1633; ILA 1633; RMG 126)] gdje je učena riječ prema knjiž. hrv. ${ }^{33}$ marèlica $(\mathrm{RHJ} 572)^{34}$

\footnotetext{
31 Tijekom pisanja ovoga rada ponovo smo provjerili termin i za nj dobili potvrdu od više ispitanika za oba značenja.

32 U značenju "šljiva": na Grobinštini ārmulîn "drvo i plod rane šljive sitnih crvenkastožućkastih plodova" (GG 150), u Medulinu armulîn "divlja šljiva" (RMG 18).

33 Radi potpune preciznostivalja dopustiti i mogućnost da je u istrorumunjski termin ušao izravno iz hrvatskoga književnoga jezika.

34 Uz sln. marệlica Marko Snoj piše: "Prevzeto in prilagojeno prek avstr. nem. Marille iz it. armellino 'marelica', kar je izpeljano na osnovi lat. Armeniacum (pōmum), dobesedno 'armensko (jabolko)'." (SES 323).
} 


\section{Smokva (Ficus carica) - stablo i plod}

I za stablo i za plod u Žejanama i Letaju smonkva, - $\boldsymbol{a}$, -e, -ele ž., u Kostrčanu smókve, - $\boldsymbol{a},-\boldsymbol{i}$, -ile ž., u Mihelima smokva, - $a$, -e, -ele ž. i smokva, -a, -i, -ile ž., ovo potonje i u svim ostalim južnim selima.

Puşcariu ima smocvę (SIr 325), Cantemir smócve (TIr 180), Sârbu i Fraţilă smocva (DIr 277). Posuđeno iz nekog čakavskog govora: npr. smökva u Brgudu, Čepiću (IrLA 1634), Svetvinčentu, Ližnjanu (ILA 1634), u Orbanićima (ČDO 548), u Medulinu (RMG 215), na Grobinštini (GG 597), u Senju (SR 135), na Braču (RBČG 875), smõkva, u Čabrunićima, Orlecu (ILA 1634; ČDOC 353), smökwa u Valturi (ILA 1634), smōkva u Labinu (RLC 250) i smòkva u Funtani (MFR 69) < mlađi prslav. *smoky (HER 566)35.

\section{Murva, dud (Morus alba, nigra) - stablo i plod}

U svim istrorumunjskim selima, osim u Žejanama i Novoj Vasi, izrijekom razlikuju bijeli i crni dud. U Žejanama i za jedno i za drugo stablo kao i za plod vele $\boldsymbol{m} \underline{u} \boldsymbol{r} \boldsymbol{y} \boldsymbol{v} \boldsymbol{a}, \boldsymbol{- \boldsymbol { a }}, \boldsymbol{- \boldsymbol { e }}$, - $\boldsymbol{e l e}$ ž., u Novoj Vasi murgve, $-\boldsymbol{a},-\boldsymbol{e}$, -ele ž. U ostalim mjestima imamo sljedeću situaciju. Naziv za plod obaju stabala jedinstven je: u Šušnjevici murgve, - $\boldsymbol{a}$, - $\boldsymbol{e}$, -ele ž., u Brdu, Škabićima, Trkovcima, Zankovcima, Mi-

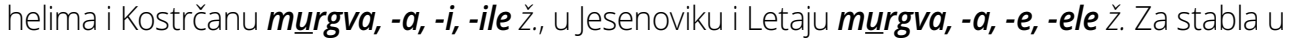
Jesenoviku murgva åba, murgva negra, u Mihelima murgva åba, murgva nggra, $u$ Letaju, Brdu, Škabićima, Trkovcima, Zankovcima i Kostrčanu åba mürgva, ng gra mürgva. Uz navedeno, u Novoj Vasi su nam još rekli da neplodan dud nazivaju murgvåč, $-\boldsymbol{u},-\boldsymbol{\emptyset},-\boldsymbol{i} m$.

Maiorescu navodi murgvă (VIrR 113), Byhan múrgvę (IrG 284), Popovici murgva (DRI 127), Cantemir múrgve (TIr 172), Sârbu i Fraţilă murgva (DIr 231), Kovačec za Žejane múryva u značenju "kupina" (IrHR 121), Dianich 'murgva (VIrl 129). Riječ posuđena iz nekog čakavskog govora: tip murgva ne možemo potvrditi u literaturi s kojom se služimo, u većini čakavskih govora i u Istri i u Dalmaciji prevladavaju oblici tipa mûrva (OA), no imamo i npr. u Vodicama mûrva i mûrga (ID 193), na Ćićariji murga (HBI 459). Skok navedene oblike (nema tipa murgva) drži ostatcima iz dalmatskoga: "Dalmato-romanski leksički ostatak od lat. mŏrus, mŏrum." (SKOK II/484, s. v. mura²). Ne možemo potvrditi ni murgvač, izvedenicu na -ač, u čakavskim govorima, samo tip bez -g-: npr. u Medulinu murvấč "dud bez ploda" (RMG 135), u Rukavcu murvãš "muško stablo od duda" (RČGR 165), u Novom Vinodolskom murvẽš "besplodno stablo murve" (RČGNV 142).

Ostaje nam još protumačiti domaće pridjeve "bijel, -a, -o" i "crn, -a, -o". Za prvi smo u Žejanama zapisali åb, åba; åb/åbi, åbe, u Šušnjevici i Novoj Vasi åb, åbc; åĺb, åbe, u ostalim juž. S. åb, åba; åĺb, åbe, u Zankovcima i åb, åbe; åĺb, åbe ${ }^{36}$. Oblik smo potvrdili i za srednji rod slavenskoga (čakavskoga) tipa: åbo; åb(i) u Žejanama, åbo; åĺb, u juž. s.: åbo de óclú "bjeloočnica", doslovce "bijelo od oka" (IrHR 20). Autori ir. repertoara kojima se služimo donose: ab, abă, abi, abe (VIr 105), ob, olb (IrG 296), åb, -ę (DRI 89), ŭab, - e (TIr 157), åb, -a (DIr 186), åb, åbę, ål'b, åbe za juž. s. i åb, åba, åb(i), åbe za Žejane (IrHR 20). Domača riječ: lat. albus, REW $331.1>$ dr., mr. alb, -ă (DEX 23, DMr 10); ar. álbu, -bă (DDAr 81), albu, -bâ (DAr 33, s. v. alb). Za "crn, -a, -o" u

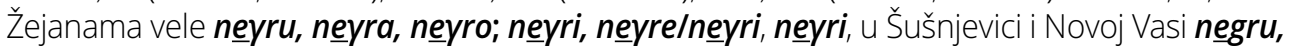
negre, negro; negri, negre, negri, u ostalim mjestima negru, negra, negro; negri, negre, negri. Byhan je zapisao négru, -rę, -ri, -re (IrG 286), Puşcariu negru, nęgrę (SIr 316), Maiorescu negru, neagră, mn. negri, negre (VIr 136), Cantemir négru, -e (TIr 172), Sârbu i Frăţilă negru, nęgre, -o (DIr 236), Kovačec négru, négrę, négri za Šušnjevicu, néyru, néyra, néyro, néyri za Žejane (IrHR 126), Radu Flora néghru, neághra; néghri, néghre za Žejane, négru, neágra; négri, neágre za Letaj, né-

35 Slavizmi su istoga krajnjega etimona i dr. smochín, smochínă "smokva: stablo, plod" (DEX 997), smokin, smokina "id." (IrLA 1634 - za Rudnu Glavu) < bug. смо̀киня (TP 731) i mr. smócfă (DMr 269) < srp. cмöква (PCJ 1246).

36 U svim se mjestima pridjev rabi i za kosu, u značenju "sijed": åĺb peri "sijede vlasi, sijeda kosa". 
gru, nęagrặ; négri za Šušnjevicu; négru, neágra; négru, neágre za Novu Vas; négru, né/a/gra; négri, négre za Jesenovik; négru, néágra; négri, négre za Brdo, Kostrčan (MALGI 239). Domača riječ: lat. niger, REW 5917 > dr., ar., mr. négru, neágră (DEX 682; DDAr 748; DMr 205).

\section{Dunja (Cydonia oblonga) - stablo i plod}

U Žejanama nismo dobili odgovor. Za stablo i plod u Šušnjevici i Novoj Vasi vele $\boldsymbol{k} u \underline{n} \boldsymbol{\varepsilon},-\boldsymbol{a},-\boldsymbol{e}$, -ele ž., u Zankovcima kuńe, -a, kuń, -i ž., u Kostrčanu kunnar, -a, kuń, -i ž., u Mihelima kuńe, -a, -e, -ele ž., u ostalim južnim selima kuńa, - $\boldsymbol{a}$, -e, -ele ž.

Od autora istrorumunjskih repertoara kojima se služimo samo Dianich navodi kunja (VIrl 118). Riječ posuđena iz nekog čakavskog idioma gdje je (istro)mletacizam: npr. u Čepiću küńa (IrLA 1636), isto u Svetvinčentu, Čabrunićima, Valturi i Ližnjanu (ILA 1636), Medulinu (RMG 110) i Belom (BBT 191), u Funtani i Pićnu kùnja (MFR 43; PI 55), u Labinu kūnja (RLC 138), na Braču küńa (RBČG 421) < mlet. cogno (BOE 17737)38: "Lat. cotoneu(m), dal gr. kydonios 'di Cidone' (Creta)." (DELI-cd).

\section{1. Šipak (Punica granatum) - stablo i plod}

Za stablo i plod u Žejanama šipak, u Šušnjevici sipąk, sipąku, sipki, sipki m. i sipạk, sipąku, sippci, sippci m., u Novoj Vasi i Mihelima šipąk, šipąku, šipąk, šipki m., u Letaju pantalisica, -a, -e, -ele ž., u ostalim mjestima šipąk, šipąku, šipki, šipki m.

Za tip šipak u Kovačeca nalazimo za Žejane şípâc (IrHR 190) i u Dianicha šipak (VIrl 168). Posuđeno iz nekog čakavskog govora: npr. šipak na Roveriji (RR), šipak u Brgudu (IrLA 1638), šipäk u Čepiću (IrLA 1638), u Čabrunićima (ILA 1638), šîpak u Svetvinčentu (ILA 1637), šĩpak (ILA 1637), šipäk na Boljunštini (RBG), Grobinštini (GG 629) i na Braču (RBČG 923) < prslav. *šipъkъ (SES 634, s. v. šīpek). Za pantalisica Cantemir donosi pánţa lişi̧̧a (TIr 174), Dianich pantali'sitsa (VIrl 139). Ne znamo protumačiti.

\section{Rogač (Ceratonia siliqua) - stablo i plod}

Za stablo i plod u Žejanama korumba, - $\boldsymbol{a}$, -e, -ele ž., u Šušnjevici i Novoj Vasi karobule, - $a$, -e, -ele ž., u ostalim južnim selima karōbula, -a, -e, -ele ž.

Žejanski naziv korumba pokriva i divlju šljivu (v. 5.1.). Od autora istrorumunjskih repertoara kojima se služimo slične oblike imaju samo Byhan i Kovačec, ali ne u značenjima koja smo mi zapisali: korúmbę "crni trn" (IrG 248) odnosno corúmba "šipak" (IrHR 53 - za Žejane) ${ }^{39}$. Mletacizam posuđen iz nekog čakavskog idioma: npr. u Medulinu, Pagu iValturi korüba (RMG 105; CGP 211; ILA 1638), u Ližnjanu korûba (ILA 1638), u Vrgadi karüba (RGV 87) ${ }^{40}$. Čakavizmi mletačkog podrijetla su i nazivi tipa karobula: npr. u Čepiću i Orbanićima karöbula (IrLA 1638; ČDO 463), u Svetvinčentu i Čabrunićima isto (ILA 1638), na Roveriij karobul (RR), u Labinu karōbula (RLC 121), u Funtani i Pićnu karòbula (MFR 38; Pi 47) - od autora istrorumunjskih repertoara kojima se služimo samo Dianich donosi ka'robula (VIrl 111). U osnovi su navedenih čakavskih oblika (istro)mlet. caròba, caròbola (BOE 140; DDP 64), caroba, caròbola (VG 178) - arabizam: harrub(a) (DELI-cd, s. v. carruba).

\footnotetext{
37 "Dicesi in Contado come sincopato di Codogno."

"kunja na Jadranu može se osnivati i na mlet. cogno < codogno." (SKOK I/557, s. v. gdünja).

Značenja koja navode Byhan i Kovačec nismo mogli potvrditi ni opetovanim provjerama na terenu.

40 Do umetanja -m-moglo je doći i unutar istrorumunjskoga.
} 


\section{Badem (Prunus amygdalus) - bajam}

Za stablo i plod u Šušnjevici i Novoj Vasi mendule, $-\boldsymbol{a}, \boldsymbol{e}, \boldsymbol{e}$, $-\boldsymbol{e l e}$ ž., u svim ostalim mjestima mendula, $-a,-e$, -ele ž.

Maiorescu ima mendulă (VIrR 112), Byhan i Puşcariu méndulę (IrG 274; SIr 314), Popovici méndule (DRI 124), Cantemir méndule (TIr 171), Dianich 'mendula (VIrl 126). Posuđeno iz nekog čakavskog idioma: npr mêndula u Brgudu, Čepiću i Medulinu (IrLA 1639; RMG 128), Ližnjanu (ILA 1639), mēndula u Labinu (RLC 155), mèndula u Pićnu (PI 63), mẽndula u Vrgadi (RVG 117), mệndula na Braču (RBČG 469). Skok hrvatske oblike tipa mendula drži dalmatskima, izvodi ih "od

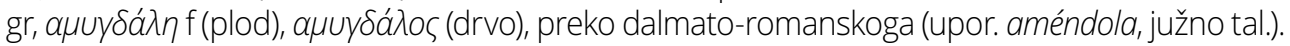
Na to vrelo upućuje romanska zamjena $u>$ e, i, ije, varijante roda f pored $m$ (čime se razlikuje plod od drva, što ne postoji u hrv.-srp.) i zamjena grupe gd > nd (...)" (SKOK II/556, s. v. omendula). ${ }^{41}$

\section{Orah (Juglans regia) - stablo i plod}

Stablo i plod izrijekom razlikuju u Šušnjevici, Novoj Vasi, Jesenoviku, Škabićima i Kostrčanu: u

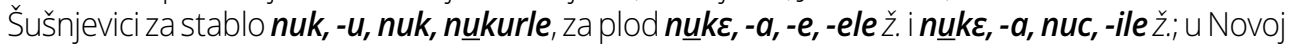
Vasi za stablo nuk, -u, nuč, -i m., za plod $n u k \varepsilon$, , $a$, -e, -ele ž.; u Jesenoviku za stablo nuk, -u, nuč, -i $m$., za plod nuka, -a, -e, -ele ž.; u Škabićima za stablo nuk, -u, -ure, -urle bg. i nuk, -u, nuč, -i m. za plod nuka, -a, -e, -ele ž.; u Kostrčanu za stablo nuk, -u, -ure, -urle bg., za plod nuka, -a, -e, -ele ž. i nukka, -a, nuč, -ile ž. U ostalim je mjestima naziv za stablo i plod jedinstven: nuk, -u, nuč, -i $m$.

Miorescu ima nuc za stablo i nucă za plod (VIrR 114), Byhan nuk za stablo i núkę za plod (IrG 290), Popovici nuc za stablo i nuce za plod (DRI 130), Puşcariu nuc za stablo i nuce za plod (SIr 317), Cantemir nuc za stablo i núche za plod (TIr 173), Sârbu i Frațilă nucă42 za plod (DIr 239), Kovačec nuc za stablo i núkę za plod (IrHR 130), Dianich 'nuk za stablo (VIrl 134). Domaća riječ: dr. nuc, núcă (DEX 701), nuk, nuka (IrLA 1640 - u Rudnoj Glavi); ar. nuc, núcă (DDAr 787); mr. nuc, núcă (DMr 208) < lat. nŭx, nŭce, REW 6009.

\subsection{Orahova ljuska}

U Žejanama vele skorca de nuk i ĺuspinan de nuk, u Šušnjevici i Novoj Vasi kora (kore, - $a$, -e, -ele ž.) de nukks, u Jesenoviku, Škabićima i Kostrčanu kora (kora, - $a$, -e, -ele ž.) de nukka, u ostalim južnim selima kora de nuk.

Svi su termini sintagme u doslovnom značenju "kora/koža/ljuska od oraha". U Brgudu köra od orëha, u Čepiću köra od orïha (IrLA 1641), u Valturi kôra od orìxa, u Ližnjanu köra od orïxa (ILA 1641).

Leksem luspina, izvedenica je od lu(s)pa (v. 14.2.). Odgovarajući oblik nalazimo samo u Dianicha: Ijupa (VIrl 124). Posuđeno iz nekog čakavskog govora: npr. u Vodicama /upïna (ID 189), u Pićnu lupina (PI 60), u Labinu lupina (RLC 147) - od lupit(i) i sl. Dalje v. 1.1.

Za oblike tipa skorca Maiorescu je zapisao scorţă (VIrR 121), Cantemir scorţe (TIr 179), Kovačec scórţa (IrHR 173 - za Žejane). Oblik bi mogao biti domaćeg podrijetla, pogotovo jer sličnih izraza u čakavskim idiomima, barem prema našim spoznajama, nema. Postoji, prema rječnicima s kojima raspolažemo, samo još u dačkorumunsjkom: scoárţă (DEX 961) < lat. scŏrtea, REW 7742. Manje je

\footnotetext{
41 Oblik méndula koji je Rosamani zapisao u Rijeci, Velom i Malom Lošinju i na Cresu moglo bi se protumačiti i kao ostatak iz predmletačkih slojeva u tim mletačkim govorima, ako nije nastao pod utjecajem okolnih hrvatskih govora - u mlet. dijalektima imamo tip mandola (BOE 391) < kasnolat. amandula(m) (DELI-cd, s. v. mandorla). 42 Vjerojatno greška jer u doba kad je nastala citirana knjiga Istrorumuni nisu izgovarali a na kraju imenica ž. r.: u toj je poziciji moguće ili a ili $\varepsilon$. Usput, veliko je pitanje je li tako bilo u doba kad je Maiorescu pisao svoj glosar, premda on imenice ženskoga roda koje danas završvaju na a ili $\varepsilon$ sustavno bilježi s finalnim a (odnosno ă u svojoj grafiji).
} 
vjerojatno da je posuđen iz nekog mletačkog govora: scorza (BOE 633), scòrsa (VG 981). ${ }^{43}$

Oblik tipa kora od autora istrorumunjskih repertoara kojima se služimo donosi samo Kovačec, córa (IrHR 53 - za Brdo). Posuđenica iz nekog čakavskog govora: npr. köra u Brgudu i Čepiću (IrLA 1723), u Svetvinčentu, Čabrunićima, Valturi, Ližnjanu (ILA 1723), u Medulinu (OA), u Orbanićima kod Žminja (ČDO 469), u Senju (SR 59), na Braču (RBČG 406) < prslav. *kora (HER 332) ${ }^{44}$.

Za nuk(a) v. 14., za de 1.2.

\subsection{Zelena orahova ovojnica}

U Žejanama su nam rekli kože de nuk, u Kostrčanu kože de nuka, u Šušnjevici i Novoj Vasi lupa de nukk, u Jesenoviku i Škabićima lupa de nukka, u ostalim južnim selima ĺupa de nuk.

Navedeni su termini metaforične sintagme u doslovnom značenju "koža/ljuska od oraha"45. U Čepiću köža od orïha (IrLA 1642), u Valturi kôža od orïxa (ILA 1642). Za lupa v. 14.1. i 1.1., za de 1.2., za nuk(a) 14.

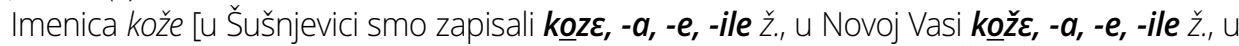
ostalim mjestima kože, $-\boldsymbol{a},-\boldsymbol{e}$, -ile ž., u svim mjestima, osim u Novoj Vasi i Šušnjevici, još i kožăa, - $a,-e$, -ele ž. i kože, - $a$, -e, -ele ž., u Šušnjevici još i kozze, - $a,-e$, -ele ž., u Novoj Vasi još i kožc, - $a,-e$, -ele ž. - Maiorescu ima cojă i coje (VIrR 100), Popovici coje (DRI 99), Cantemir cóje (TIr 162), Sârbu i Fraţilă coja (DIr 198), Kovačec za Šušnjevicu cóze, za Novu Vas i Žejane cóže (IrHR 54)] u potpunosti se poklapa s čakavskim oblicima tipa koža [npr. u Svetvinčentu i Čabrunićima köža (ILA 1642), u Labinu kōža (RLC 133), na Braču köža (RBČG 406) < prslav. *koz'a (SES 267)], no ipak čini nam se ekonomičnijim pretpostaviti da je riječ o izvornim oblicima, slavenskog podrijetla i u drugim rumunjskim dijalektima: dr. coájă (DEX 190); ar. coáje (DDAr 300), coaji (DAr 266, s. v. coajă), coaji (DArM 134); mr. coájă (DMr 74) - uz navedene dr. i ar. oblike daje se značenje "kora, ljuska", dok Capidan mr. riječ tumači kao "piele", dakle "koža (u živih bića)"46.

\subsection{Orahova jezgra}

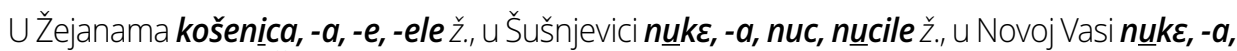

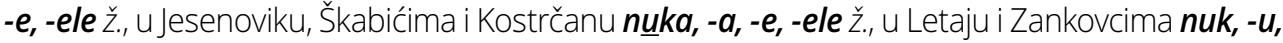
nuk, -ile ž., u Brdu, Trkovcima i Mihelima nuk, -u, nuč, -ile ž.

Osim u Žejanama za orahovu jezgru nazivi se poklapaju s nazivima za orahov plod (v. 14.)47.

Za žejanski naziv ne nalazimo potvrdu u ir. repertoarima kojima se služimo, a odgovarajućih oblika nema ni u čakavskim rječnicima, pa ćemo pitanje tumačenja ovoga oblika, barem za sada, ostaviti otvorenim.

\subsection{Dio orahove jezgre}

U Žejanama suppica (suppica, - $\boldsymbol{a}$, -e, -ele ž.) de nuk, u Šušnjevici picoricu de nukk, u Novoj Vasi pičoriču de nukk, u Jesenoviku i Škabićima kokotiču de nuka, u Jesenoviku i pičorica de nukka, u

\footnotetext{
43 Iste su etimologije i tal. scòrza ["Lat. scortea(m) 'pelliccia', f. sost. di scorteus 'di pelle, di cuoio' (da scortum 'pelle, cuoio', da awicinare a corium 'cuoio')." (DELI-cd)] i istriotski u Rovinju s'kursa, u Balama, Vodnjanu i Galižani śkorśa, u Fažani šk'kortsa, u Šišanu škursa (ILA 1723).

44 "Pslovan. *(s)kori, rod. (sc. genitiv) *(s)korbję 'nekaj koži podobnega', je izpeljano iz pslovan. *(s)kora '(odrta) koža, (neustrojeno) usnje'. Beseda je prvotno pomenila *'rezanje, striženje', nato *'kar je odrezano' in končno 'koža'. (SES 574).

45 U Rudnoj Glavi kuąža đi nukka (IrLA 1642).

46 Za ir. smo također potvrdili to značenje.

47 Tako je i u mnogim čakavskim govorima: npr. u Brgudu orëh (IrLA 1643), u Svetvinčentu, Čabrunićima i Ližnjanu orïx (ILA 1643) < prslav. * orěxъ (SES 411).
} 
Kostrčanu pičoriču de nuka, u Letaju kokotiču de nuk, u ostalim južnim selima pičoriču de nuk.

Sve sintagme u doslovnom značenju "kriškica/pijetlić/nožica od oraha (ploda)". U ovom ćemo odjeljku obraditi prve elemente sintagmi (za nuk, nuka v. 14., za de 1.2.).

Žejansko suppica umanjenica je na -ica od suppa "kriška" Riječ je u tom značenju poznata i u drugim istrorumunjskim selima: u Šušnjevici i Novoj Vasi zapisali smo sup $\boldsymbol{\varepsilon},-\boldsymbol{a}$, - e, -ele ž., u svim ostalim južnim selima supa, $-\boldsymbol{a},-\boldsymbol{e}$, -ele ž. Od autora istrorumunjskih repertoara kojima se služimo samo Dianich ima 'supa "kriška" (VIrl 165). Posuđeno iz nekog čakavskog govora: npr. u Pićnu sùpa "šnita, kriška" (PI 107), u Medulinu süpa "kriška, komad (süpa palênte)"'48 (RMG 221), na Boljunštini süpa "kriška, komadić, odrezak kruha" (RBG); u većini drugih mjesta značenje je riječi "kruh udrobljen u vino i sl."49: u Brgudu i Čepiću süpa "popečeni kruh u kuhanom crnom vinu" (OA), u Labinu sūpa "kruh udrobljen u posebno pripremljeno vino, u kojem se nalazi maslinovo ulje i papar" (RLC 260), u Orbanićima süpa "dish consisting of bread, soaked in whipped eggs, than baked and put into red wine" (ČDO 554), na Grobinštini süpa "juha od kruha natopljena vinom" (GG 619), na Braču süpa "umak, tekućina u koju se što umače" (RBČG 902), u Belom na Cresu süpa "jelo od kruha i vina; pčelinje saće" (BBT 444), u Kolanu na Pagu süpa "vino u koje je namočen baškotin ili zapečeni kruh" (RKGP 482), u Kukljici süpa "u hladnoj vodi sitno narezan kruh uz dodatak soli, ulja i octa; umjesto vode upotrebljava se i vino" (RGK 281), u Salima süpa "jelo od udrobljenog kruha u bevandu" (RGS 344), u Visu sùpa "močenje kruha ili kojeg slatkog peciva u vino ili prošek" (LVJ 522)50. Riječju u značenju "kruh umočen u vino; juha" pozabavio se i Skok: "Od sttal. suppa, mlet. supa, tal. zuppa "10 minestra di pane nel brodo, $2^{\circ}$ pane intinto nel vino" < germ. suppa. Balkanski talijanizam (...)" (SKOK III/363)51.

Prvi elemenat sintagmi tipa pičoriču/pičorica de nuk metaforičan je, umanjenica na -ičl-ica od pičor "stopalo, noga": u Žejanama smo zapisali pičôr, -u, -e, -ele m., u Šušnjevici picor, -u, -e, -ele bg., u Letaju pičór, -u, -ø, -i m., u ostalim južnim selima pičôr, -u, -e, -ele bg., u Novoj Vasi, Jesenoviku, Zankovcima i Mihelima još i pičorr, -u, -ø, -i m. - Maiorescu ima picior (VIrR 117), Popovici pićor (DRI 135), Cantemir piciór (TIr 175), Sârbu i Fraţilă pițor (DIr 249), Kovačec pičór (IrHR 146) i za Šušnjevicu piţór (IrHR 147), Dianich pičórići pičcwor (VIrl 142). Domaća riječ: dr. piciór (DEX 788); dr. čičór (DDAr 354), cior (DArM 166); mr. pitšór (DMr 224) < lat. pěciǒlus, REW 6324a.

Prvi dio sintagme kokotiču de nuk(a) metaforičan je, umanjenica na -ič od kokot "pijetao": za pijetla smo u Żejanama zapisali kokotić, $-\boldsymbol{u},-\varnothing,-\boldsymbol{i}$ m., u Trkovcima, Zankovcima i Mihelima kokotič́, -u, -ø, -i m., u Šušnjevici i Kostrčanu kokot, -u, kokoc, -i m., u ostalim juž. s. kokot, -u, -2, -i m., u Novoj Vasi, Brdu i Škabićima množina još i kokoc, -i - Byhan navodi kokót (IrG 244), Popovici, Cantemir i Kovačec cócot (DRI 99; TIr 162; IrHR 51), Puşcariu cocot (SIr 306), Sârbu i Fraţilă cocot (DIr 198), Dianich koko'tić "galletto" (VIrl 114). Posuđeno iz nekog čakavskog govora prije dolaska na Krki u Istru52: npr. na Braču i u Korčuli kökot (RBČG 386; RGGK-cd), u Visu kòkot (LVJ 227) < prslav. onomat. *koko (SES 245, s. v. kokộš).

\footnotetext{
48 I u značenju koje ćemo navesti dalje u tekstu.

49 Riječ za to jelo imaju i Istrorumunji: odgovara već navedenim oblicima tipa supa, uz napomenu da se u Letaju može reći i supa de negru vir, a u Škabićima i Zankovcima supa de vir, sintagme u doslovnom značenju "umak od crnog vina" odnosno "umak od vina": za "vino" smo u Žejanama zapisali vir, - u, - ure, -urle m., u svim juž. s. vir, -u, -ure, -urle bg., a u ir. repertoarima kojima se služimo nalazimo također vir (IrG 381, SIr 329, VIr 156, DRI 164, TIr 186, DIr 298, IrHR 214, VIrl 183) < lat. vīnum, REW 9356 > dr. vin (DEX 1162), ar. v́in (DER 9266), mr. vin (DMr 327). 50 Usp. i glagol: u Labinu sūpat "umakati, umočiti kruh u supu" (RLC 260), süpat "sop (bread in red wine)" (ČDO 554), u Medulinu süpati "namakati kruh u tekuću hranu da bude gušće, ili u piče" (RMG 221), u Orlecu sùpat "sop (e. g. bread)" (ČDOC 360), na Grobinštini süpat "umakati kruh u tekućinu (najčešće u kuhano vino)" (GG 619), na Braču süpot "umakati u što" (RBČG 902), u Belom na Cresu süpat "supati (...)" (BBT 444), u Kolanu na Pagu süpat "umakati kruh u vino i polako jesti i piti" (RKGP 483), u Kukljici süpati "kruh umakati u umak" (RGS 281), u Salima süpati "umakati u umak" (RGS 344), u Visu supât" "močiti, namakati kruh ili kakvo slatko pecivo u vino ili prošek" (LVJ 523).

51 Iste je etimologije i sIn. župa "juha": "Prevzeto iz srvnem. suppe" (SES 767).

52 Tip kokot, barem prema našim spoznajama, nije u uporabi u sjevernim čakavskim govorima.
} 


\subsection{Orahova ljuska iz koje je izvađena jezgra}

U Žejanama dešarta ĺuspina, u Šušnjevici i Novoj Vasi pråzne nuk $k$, u Letaju prazzan nuk, u Zankovcima pråzna lupa, u Śkabićima luppa, - $a$, -e, -ele ž., u Jesenoviku korele de nukka ž., u osta-

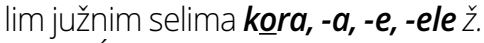

Za lupav. 14.1. i 1.1., za nuk 14., za kora 14.1. Ostaje nam obraditi dva pridjeva, oba u značenju "prazan".

Pridjev dešart (čuli smo i dešårt), - $a,-0 ;-i,-e,-i$ u Žejanama se koristi u značenju "prazan" i, rjeđe, "pust" [prvo značenje daje i Kovačec: deşårt za Žejane (IrHR 155, s. v. pråzân)], a u južnim selima tip dešert (u Šušnjevici smo zabilježili desertt, $-\varepsilon$, -0 ; deserert, $-\boldsymbol{e}$, $-i$, u Novoj Vasi dešertt, $-\varepsilon$, $-o$; dešert, $-e,-i$, u ostalim južnim selima dešert, $-a$, -0 ; dešert, $-e,-i$ ) koristi se gotovo isključivo u značenju "pust, opustošen"53 [vjerojatno su samo to značenje imali na umu Sârbu i Fraţilă koji uz deşert, deşerta, deşerto navode "pustiu, deşert, părăsit"54 (DIr 206)]. Domaća riječ: dr. deşért, -ártă (DEX 291); ar. dişértu, -eártă (DDAr 403), dishirtat, dishirtatã (DArM 203); mr. diş̧rrt/dişărt, dişartă (DMr 112) < lat. dēsërtus, REW 2592.

Tip prazan [u Šušnjevici i Novoj Vasi zapisali smo pråzan, pråzne, pråzno; pråzni, pråzne, pro̊zni, u Letaju i Kostrčanu prazzan, prazzna, prazzno; prazzni, prązne, prazzni, u ostalim južnim selima i Žejanama pro̊zan, pråzna, pro̊zno; pråzni, pråzne, pråzni - Popovici ima pråzăn, -zna, -zno (DRI 139), Puşcariu pråzăn, -znę, -zno (SIr 321), Cantemir prázăn, -ne (TIr 176), Sârbu i Fraţilă prazăn, -zna, -zno (DIr 258), Kovačec za Novu Vas pråzân, pråznę (IrHR 155)] posuđen je iz nekog čakavskog govora: npr. na Boljunštini prāž̃n (RBG), u Orlecu na Cresu prãzen i prazën (ČDOC 333), na Grobinštini prāzân (GG 519), u Orbanićima, Medulinu, Funtani i Senju prâzan (ČDO 527; 187; MFR 61; SR 115), u Vrgadi proâzan (RVG 166) < prslav. *porzdınъ (SES 485). Usp. u Brgudu präzna köra (IrLA 1645).

\subsection{Prazan orah}

U Žejanama smo zapisali dešart nuk, u Jesenoviku i Kostrčanu pro̊zna nukka, u Škabićima prázna nuka, u Šušnjevici i Novoj Vasi pråzne nuke, u ostalim južnim selima prązan nuk.

Za nuk(a) v. 14., za dešart i prazan 14.5.

Usp. u Brgudu prâzan orëh, u Čepiću prazän orïh (IrLA 1646)

\section{Lijeska (Corylus avellana) - lješnjak}

Samo u Žejanama izrijekom razlikuju stablo i plod: za stablo vele liska, - $a$, lišt, lištile ž., za plod alure, -a, alur, alurle ž. Za stablo i plod u Šušnjevici lisńak, -u, lisńace, -ele bg., u Jesenoviku, Letaju, Trkovcima i Mihelima lišńak, -u, lišńače, -ele bg., u Zankovcima lišńak, -u, lišńač, lišńaki m., u ostalim južnim selima lišńak, -u, -ø, lišńaki m.

U Žejanama za stablo rabe posuđenicu (liska - v. niže), a domaću riječ (alure) za plod55. Byhan ima alur, -ri za stablo, alure, -re za plod (IrG 186), Popovici alur, -u, mn. -iza stablo i alure, mn. -e za plod (DRI 87), Sârbu i Fraţilă alura za plod (DIr 187), Kovačec za Žejane alúre, -a, alúr, -le"lješnjak" (IrHR 22). Dr. alün za stablo i alüna za plod (IrLA 1647 - u Rudnoj Glavi), alún, alúnă (DEX 31); ar. alún, alúnă (DDAr 86, 87), alunu, -ńi, alunâ, -i (DAr 41, 42), alun, alunã (DArM 22), alúna (ADK 196); mr. lun, lună (DMr 175) < lat. abĕllāna, REW 17.

Žejanski naziv liska [Popovici je za Šušnjevicu zabilježio lisce, - - a u značenju "lijeska" (DRI

\footnotetext{
53 Tijekom pisanja ovoga rada provjerili smo oblik i za značenje "prazan" i dobili potvrdu samo od jednog ispitanika uz napomenu da su je tako u vrijeme njegova djetinjstva upotrebljavali samo jako stari ljudi.

54 Jedino "pust" sadrže sva tri oblika.

55 Ni opetovanim provjerama tijekom pisanja ovoga rada nismo uspjeli potvrditi domaći naziv tipa alur za lješnikov grm.
} 
120), Puşcariu bez naznake mjesta liscę u značenju "lješnjak" (SIr 313) - v. dalje] po svoj je prilici posuđen iz nekog čakavskog govora. Problem je što u čakavskim rječnicima kojima se služimo ne možemo potvrditi taj leksem, a sami ga također nikada nismo čuli - ipak: "(ekavski, također kod čakavaca) léska (ŽK) = (ikavski) liska = (prijelaz u maskulinum prema orah) lesäk, gen. leskä (Istra)56" (SKOK II/298, s. v. lijèska). Moguće je i da je oblik preuzet iz neka bliza slovenskog govora: léska (MtP-cd), léska (SSKJ-cd) - po svoj prilici govora gdje se [e] izgovara jako zatvoreno (skoro [i]) jer bi inače bilo *leska što bi u istrorumunjskim govorima bilo također moguće. Ni za te sln. oblike nemamo potvrda. Bilo kako bilo, krajnji je etimon prslav. *lěska (SES 299, s. v. lẹ́ska).

Nazivi tipa lišńak nedvojbeno su čakavski [Puşcariu lisńåák za stablo (SIr 313), Kovačec lişńak, -u, lişńnač "lješnjak" (IrHR 105), Dianich "išnjak, -u, mn. "lišnjači za plod (VIrl 132)]: npr. u Brgudu lêšńak za plod, u Čepiću lišńak i za stablo i za plod (IrLA 1647), u Svetvinčentu, Čabrunićima, Valturi i Ližnjanu lišńak i za stablo i za plod (ILA 1647), u Medulinu lišnjak"lješnjak" (RMG 117), u Pićnu lèšnjaki "lješnjaci" (PI 57), u Labinu lēšnjak "lješnjak" (RLC 143), u Funtani lišnjak "lješnjak" (MFR 45), u Orbanićima lešnjãk i za stablo i za plod (ČDO 480), u Novom Vinodolskom /ĩ̌njāk "lješnjak" (RČGNV 121), u Belom na Cresu lẽšnjak i za stablo i za plod (BBT 200), na Grobinštini lišnjāk "lješnjak" (GG 350) < prslav. *lěččbnikъ (SES 299, s. v. lẹšnik).

\section{Kesten (Castanea sativa) - stablo i plod}

I za stablo i za plod u svim selima zapisali smo koståń, -u, koståń, -i m., u Žejanama i marunn, $-u,-\varnothing,-i m$.

Popovici donosi costań (DRI 101), Puşcariu coståń (SIr 307), Kovačec coståń (IrHR 54). Posuđeno iz nekog čakavskog govora: npr. u Brgudu kostâń, u Čepiću kostäń (IrLA 1648), potonje i u Svetvinčentu, Čabrunićima i Ližnjanu, u Valturi kustäń (ILA 1648), u Medulinu kostäń (RMG 105), u Orbanićima kostãnj (ČDO 470), u Labinu kostōnj (RLC 132), u Pićnu kostònj (PI 52), na Grobinštini kostãnj (GG 322), u Orlecu na Cresu kostãnj (ČDOC 275), u Belom na Cresu kostãnj (BBT 179). U osnovi je naziva lat. castanea, REW 1742.1. koje se u (istro)mletačkom razvilo u castagna (BOE 146; VG 187), castàgna (DDP 66) "kestenov plod" pa je u čakavskom došlo do promjene roda ili prema drugim nazivima za stabla ili pak posredstvom talijanskoga castagno "stablo kestena" (DLI-cd) $\leftarrow$ castagna "plod kestena" (DLI-cd). Mislimo da je ovo, kada je riječ o čakavskim govorima ipak ekonomičnije od izravnog preuzimanja iz talijanskoga jezika57 - istina, mletački idiomi za stablo kestena rabe izvedenice tipa castagner: castagnèr (BOE 146; DDP 66), castagner (VG 187), no u našem slučaju (kad je u pitanju stablo čiji se plodovi jedu) logično je da se pri međusobnim kontaktima naziv za plod prije posudio nego naziv za stablo. S obzirom na distribuciju navedenih čakavskih oblika, čini se da su ih Istrorumunji preuzeli nakon što su napustili Cetinsku krajinu, no mogli su ih pokupiti i tijekom selidbe, možda u Lici, npr. u Kompolju kostânj (RGČ 328) - ipak, izraz postoji i južnije, npr. u štokavskom dubrovačkom govoru kòstanj (RDG 188), u Boki kostänj (SKOK II/164, s. v. kostan), kostanj "zabilježeno u južnoj Hrvatskoj, na dubrovačkom području i drugdje u Dalmaciji" (HBI 319, s. v. kostanj). I na kraju, kako riječ postoji i u ostala tri rumunjska dijalekta [dr. castán, castánă (DEX 143); ar. căstînn'ú, căstînn'e (DDAr 279); mr. castǫń, castǫńă (DMr 64), mogli bismo je protumačiti kao izvornu, uz prilagodbu prema hrvatskim oblicima.

Žejansko marun [Byhan ima marún (IrG 273), Kovačec marún (IrHR 113)] posuđeno je iz nekog čakavskog idioma: npr. u Medulinu marûn (RMG 127), u Funtani također (MFR 47), u Labinu

56 U Brgudu lesäk (IrLA 1647).

57 Što je slučaj za sln. kóstanj (MtP-cd): "Prevzeto iz it. castagno 'kostanjevo drevo', castagna 'kostanjev plod', kar se je razvilo iz lat. castanea, izposojenke iz gr. kástanon 'kostanj'. Gr. beseda je verjetno izposojena iz nekega maloazijskega jezika." (SES 263). 
marūn (RLC 153), u Pićnju maròn (PI 62), u Kolanu na Pagu marûn (RKGP (235), potonje i u Korčuli (RGGK-cd), u Belom na Cresu marũn (BBT 215), potonje i na Braču (RBČG 462). Hrvati su pak riječ posudili od Mlečana: maròn (BOE 400; DDP 159), maron (VG 596), marón (DDC 126) < lat. *marro, -ōne, REW 5375.

\subsection{Divlji kesten (Aesculus hippocastanum)}

\section{U Žejanama divju koståń, u južnim selima divíu koståń.}

Za divju i divlu v. 3.1., za koståń 16.

U Brgudu divvli kostâń, u Čepiću divvli kostäń (IrLA 1745), u Svetvinčentu, Čabrunićima i Valturi dïbńi kostäń, u Ližnjanu dĩmńi kostäń (ILA 1745), u Medulinu dìmńi kostäń (OA).

\section{Oskoruša (Sorbus domestica) - stablo i plod}

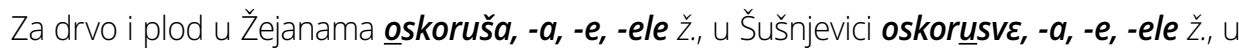
Novoj Vasi oskorušve, $-\boldsymbol{a}$, - $\boldsymbol{e}$, -ele ž., u Jesenoviku i Škabićima oskoruš̌va, $-\boldsymbol{a}$, - $\boldsymbol{e}$, -ele $\check{z ̌}_{\text {., }} \mathrm{u}$ Brdu,

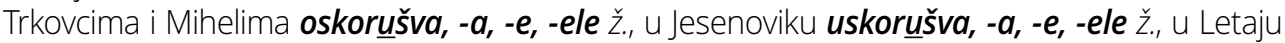
skoruštva, - $a$, -e, -ele ž., u Zankovcima i Kostrčanu skorušva, - $a$, -i, -ile ž.

Autori istrorumunsjkih repertoara kojima se služimo ne donose odgovarajućih oblika. Kako postoji u dr. ${ }^{58}$ [(scorúş, scorúşă < bug. skoruša (DEX 963), u Rudnoj Glavi skoruš za stablo i skoruša za plod (IrLA 1649)], možda je domaća riječ s kasnijim prilagodbama prema čakavskim oblicima: npr. u Brgudu öskoruša, u Čepiću šköruša i skörušva (IrLA 1649), u Čabrunićima i Ližnjanu öskoruša, u Valturi oskorüša (ILA 1649), u Pićnu skòrušva (PI 102), na Grobinštini öskoruša, öskoruška, öskorušva (GG 444), na Braču osköruša (RBČG 617), u Splitu òskoruša (StR 219), u Korčuli sköruša (RGGK-cd). "Dovodi se u vezu sa skora (v. kora $\left.{ }^{59}\right)$, tako da bi o- bio prefiks a -uša sufiks." (SKOK II/570).

\subsection{Kupiti, vezati usta (o oskoruši)}

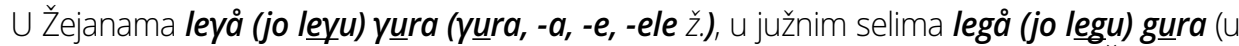
Šušnjevici i Novoj Vasi gurre, - $\boldsymbol{a},-\boldsymbol{e}$, -ele ž., u ostalim južnim selima gura, - $\boldsymbol{a}$, -e, -ele ž., u Škabićima

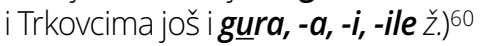

Taj osjećaj koji stvara oskoruša u ustima u mnogim se jezicima i govorima opisuje kao vezivanje [npr. u im. u Puli la 'šorbola 'liga i 'denti, oskoruša veže zube." (ILA 1650); u istriotskom govoru u Balama la 'śorba llega la 'boka, u Galižani la 'śorba 'liga la 'boka "oskoruša veže usta", u Vodnjanu la 'śorbola 'liga, u Funtani la 'šorbola 'liga, u Šišanu la 'šorbo 'liga "oskoruša veže" (ILA 1650); u čakavskom govoru u Brgudu vêže ûsta (IrLA 1650)] pa pretpostavljamo da su i Istrorumunji opisali okus oskoruše bez utjecaja okolnih idioma, u ovom slučaju rabeći samo domaće riječi (dakako, isto bismo zaključili i da su koristili posuđenice). Ostaje nam obraditi imenicu gura "usta" i glagol legå "vezati"61:

Za "usta" Maiorescu navodi gură (VIrR 107), Popovici gure (DRI 113), Sârbu i Fraţilă gura (yura) (DIr 216), Kovačec gúrę za Šušnjevicu i Novu Vas i yúra za Žejane (IrHR 87), Dianich 'gura (VIrl 106): dr., ar., mr. gúră (DEX 438; DDAr 507; DMr 147) < lat. gŭla "grkljan", REW 3910; za "vezati" Byhan

\footnotetext{
58 Za ar. imr. nemamo potvrdu.

59 Za etimologiju v. 14.1.

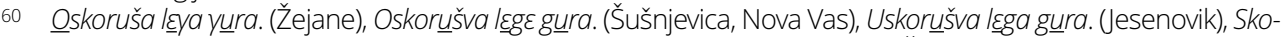

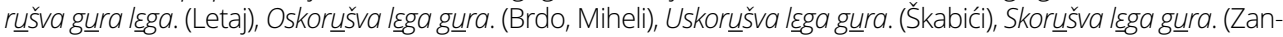
kovci, Kostrčan) - "oskoruša veže usta.".

$61 \cup$ južnim smo selima zabilježili i trajni oblik toga glagola ("vezivati"): u Šušnjevici legavẹj (jo legavess), u ostalim južnim selima legavesj (jo legaves) - Cantemir je zabilježio legavéi (TIr 169), Kovačec za Jesenovik legavęí (IrHR 103).
} 
ima legó (IrG 263), Puşcariu legå (SIr 313), Cantemir legá (TIr 169), Sârbu i Fraţilă legå (DIr 222), Kovačec legå za južna sela i leyå za Žejane (IrHR 103), Dianich le'gwa (VIrl 121): dr. legá (DEX 565); ar. leg (DDAr 624); mr. leg (DMr 168) < lat. liggāre, REW 5024.

\section{Mušmula, nešpola (Mespilus germanica) - stablo i plod}

Za stablo i plod u Žejanama méčkula, $-\boldsymbol{a},-\boldsymbol{e}$, -ele ž., u Letaju mešpula, $-\boldsymbol{a},-\boldsymbol{e}$, -ele ž. Ostali ne poznaju.

Autori istrorumunjskih repertoara kojima se služimo nemaju odgovarajućih oblika. Posuđeno iz nekog čakavskog govora: npr. na Grobinštini i Novom Vinodolskom mëškula (GG 367; RČGNV 134), u Medulinu mêškula (RMG 128), u Žrnovnici kod Splita i Ližnjanu mešpula (HBI 428), u Žrnovnici i mespula (HBI 428), u Svetvinčentu i Ližnjanu62 mëškula (ILA 1651), U Čabrunićima mïškula (ILA 1651), u Rukavcu mëškulja i mëškuja (RČGR 158). Krajnji je etimon navedenih oblika lat. měspı̌lus, REW 5540.1 (< grč. méspilon, DELI-cd). Početno m- moglo bi ukazivati na to da je riječ o predmletačkom ostatku u čakavskim istarskim govorima, a ne o glasovno promijenjenim mletacizmima - (i)mlet. nèspola (BOE 440; VG 679; DDP 174; DDC 140) odgovara čakavskim oblicima tipa nešpula (koji su češći): npr. na Boljunštini, na Braču i u Korčuli nëšpula (RBG; RBČG 554; RGGK-cd), u Labinu nēšpula (RLC 174), u Pićnu nèšpula (PI 72), u Medulinu, u Valturi nëšpula (ILA 1651), u Brgudu nëčkula, nëšpula (IrLA 1651) ${ }^{63}$. No valja dopustiti i mogućnost da je do promjene inicijalnoga fonema moglo doći i preko stand. hrv. müšmula (RHJ 623). Promjena -š- $\rightarrow$-č- u Žejanama nastala je po svoj prilici in loco.

\section{Limun (Citrus limon) - stablo i plod}

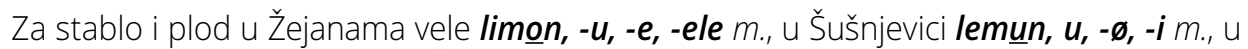
Kostrčanu lemonn, - $u,-\boldsymbol{\emptyset},-\boldsymbol{i}$ m., u Škabićima limunn, - $\boldsymbol{u}$, -e, -ele bg., u ostalim južnim selima limun, $-u,-\varnothing,-i m$.

Od autora istrorumunjskih repertoara kojima se služimo Popovici ima lemun (DRI 119), Dianich le'mun (VIrl 121) i li'mun (VIrl 122). Posuđeno iz nekog čakavskog govora: npr. u Čepiću limûn (IrLA 1652), isto u Svetvinčentu, Čabrunićima, Valturi, Ližnjanu (ILA 1652), u Funtani (MFR 45), u Medulinu (RMG 117), u Orlecu lemũn (ČDOC 287), u Labinu limôn (RLC 145), u Pićnu limòn (PI 58), u sjevernoj Istri i Kvarneru lemûn (OA), na Braču limũn (RBČG 438): "Kao u mnogim drugim slavenskim jezicima (...), iz tal. limone64, što je iz arap. laimūn, a to iz perz. limū(n), to pak iz nekog indijskog jezika ili je možda krajnji izvor malaj. IImau." (HER 377). Navedeni čakavski oblici potječu od (istro)mletačkih: limòn (BOE 372), li'mon (ILA 1652), limon (GDDT 331).

\section{Naranča (Citrus aurantium) - stablo i plod}

Za stablo i plod u Žejanama narånže, $-\boldsymbol{a}$, - $\boldsymbol{e}$, - ele ž., u Šušnjevici narånc $\varepsilon,-\boldsymbol{a}$, narånc, -ile ž., u Novoj Vasi narånč $\boldsymbol{\varepsilon}$, $\boldsymbol{a}$, - $\boldsymbol{e}$, -ele ž., u Jesenoviku, Zankovcima i Kostrčanu narånče, $-\boldsymbol{a}$, narånč, -ile ž., u ostalim južnim selima narånče, $-\boldsymbol{a},-\boldsymbol{e}$, - ele ž.

Byhan je zapisao narọ́ntŝę (IrG 286), Cantemir naránce (TIr 172). Posuđeno iz nekog čakav-

\footnotetext{
62 U Ližnjanu za stablo vele meškulêr (ibidem) - prema (i)mlet. nespolèr (BOE 440; DDC 141; DDP 174), nespoler (VG 697).

63 Za tal. nespola Meyer-Lübke rekonstruira etimon * něspillus, REW 5540.1, a u DELI-cd, s. v. nèspolo, stoji samo mĕspilu(m).

64 "Vc. ar. e pers. (IImūn), prob. da una lingua or., introdotta in Occidente, assieme al frutto, che designa, con i Crociati." (DELI-cd).
} 
skog govora: npr. u Čepiću narônča, u Brgudu narânča (IrLA 1653), potonje i u Svetvinčentu, Čabrunićima, Valturi i Ližnjanu (ILA 1653), u Orbanićima narãnča (ČDO 500), na Grobinštini isto (GG 400), u Funtani narânca (MFR 52), u Medulinu narânča (RMG 143), na Murteru narậnža (RGOM 176), na Vrgadi naroãnža (RGV 130), u Orlecu na Cresu narãnža (ČDOC 304), u Senju isto (SR 84) < (i)mlet. naranza (BOE 436), narànsa (DDC 139; DDP 173) < perz. nāräng, REW 1653. Čakavski oblici tipa naranča upućuju na moguću kontaminaciju ili sa stand. hrv. nàrānča (RHJ 651) ili tal. arancia (DLI-cd) - a možda su i učeni.

\subsection{Kriška naranče}

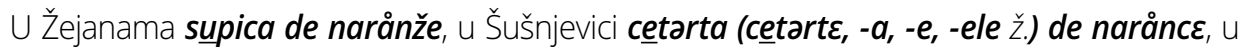

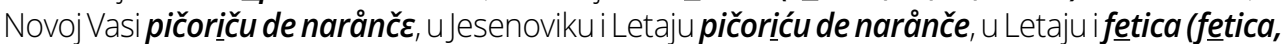

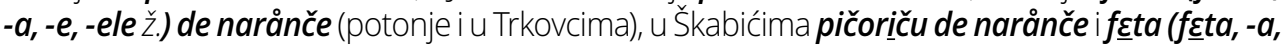

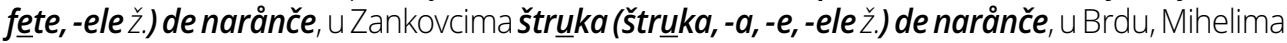
i Kostrčanu supa (supa, -a, -e, -ele ž.) de narånče.

Sintagme u značenju "kriška od naranče". Za naranče v. 20., za supa/supica i pičoriču 14.4, za

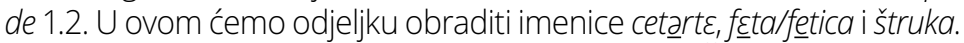

Sintagma cetarta de naråncદ koju smo zapisali u Šušnjevici znači doslovce "četvrt, četvrtina naranče", što semantički zapravo ne odgovara referentu jer jedna kriška naranče nije zapravo četvrt naranče, no kada se naranča dijeli obično svatko dobije po četvrt. U drugim selima riječ za četvrt ne označuje i krišku naranče: u Novoj Vasi smo zabilježili četarte, $-\boldsymbol{a}, \boldsymbol{-} \boldsymbol{e}, \boldsymbol{e}$ - $\mathbf{e l e}$ ž., u ostalim južnim selima četarta, - $\boldsymbol{a}, \boldsymbol{-}$ - , - ele ž. [Puşcariu ima ţetrtę "četvrt" (SIr 328), Dianich “četarta "quarto (taglio di carne), 'četarta de ga'ljire, un quarto di pollo" (VIrl 90)], u Žejanama za "četvrt" kažu kao i za "četvrtina", četartịna, $-\boldsymbol{a}, \boldsymbol{-}-\boldsymbol{e}$, - $\boldsymbol{e l e ~ z ̌ . ; ~ t i p ~ j e , ~ u ~ z n a c ̌ e n j u ~ " c ̌ e t v r t i n a " , ~ u ~}$ uporabi i u južnim selima: u Šušnjevici cetartinne, $-\boldsymbol{a},-\boldsymbol{e}$, -ele ž., u Novoj Vasi četartinne, $-\boldsymbol{a},-\boldsymbol{e}$, -ele ž., , u ostalim južnim selima četartina, - $\boldsymbol{a}$, -e, -ele ž. [Sârbu i Fraţilă navode četârtina "četvrtina" (DIr 204)], u Letaju i Jesenoviku još i četvartinna, $-\boldsymbol{a}$, $-\boldsymbol{e}$, - ele ž. [iz stand. hrv.: četvrtina (RH] 143)]. Osim potonjega preuzeto iz nekog sjevernočakavskog idioma: npr. u Vodicama čëtvrt, čêtrt (ID 163 - uz napomenu: "samo za oznaku četvrtine mesa, upravo polovice prednjega ili stražnjega dijela janjeta, ovce itd. - inače se kaže kvärat"), na Boljunštini čëtrt "četvrtina, četvrt" (RBG); u Medulinu i na Grobinštini četrtĩna (RMG 38; GG 207)65 - izvedenice od četiri [npr. na Boljunštini, Grobinštini i Braču četïri (RR; GG 207; RBČG 160) < prslav. *četÿre (HER 177)]. Istrorumunjske su imenice tipa četarta u odnosu na polazne oblike tipa čětrt promijenile rod zadržavši naglasak.

Oblici tipa feta de narånče [od autora istrorumunjskih repertoara kojima se služimo samo Dianich donosi 'feta i 'fetitsa u značenju "kriška; kriškica" (VIrl 101)] kalkirani su (ili pak stvoreni unutar istrorumunjskoga od domaćih i preuzetih elemenata) prema čakavskim modelima: npr. u Čepiću fëta narônče (IrLA 1654), u Svetvinčentu i Ližnjanu fëta od narânče, u Valturi fëta ud narânče, u Čabrunićima fëtitsa ud narânče (ILA 1654). Oblici tipa feta "kriška" (i hibridne umanjenice tipa fetica) mletacizmi su opće poznati u svim čakavskim idiomima: npr. u Orbanićima, na Boljunštini, na Murteru fëta (ČDO 442; RBG; RGOM 85), na Roveriji feta (RR), u Labinu fēta (RLC 87), u Pićnu fèta (PI 32), u Funtani, Medulinu, na Grobinštini, na Braču, u Splitu fëta, fëtica (MFR 29; RMG 63; GG 248, 249; RBČG 230; StR 74), u Orlecu fẽta (ČDOC 239) < mlet. feta (BOE 267; VG 370; GDDT 230), fèta (DDP 107), féta (DDC 77) < lat. ŏffa, REW 6041a. ${ }^{66}$

Istrorumunjskih oblika tipa štruka ne nalazimo u autora ir. repertoara kojima se služimo67.

65 Južnije su u uporabi isključivo oblici s -v-tipa četvrt(ina).

66 "Ė opinione comune (...), ma non del tutto certa, che la vc. derivi da un *offetta, dim. di offa (...), attrav. un passaggio *l'offetta > la fetta." (DELI-cd).

67 Mi smo ga zabilježlli samo u Zankovcima. 
Sličnih imenica ne nalazimo ni u čakavskim rječnicima koje imamo na raspolaganju. Oblik povezujemo s čakavskim glagolima tipa štrukat(i) "cijediti": [samo Byhan donosi glagol ŝtrokuléi (IrG 354) - što zapravo odgovara čak. glagolima tipa štrokulivat(i))] npr. u Labinu štrukàt (RLC 276), u Medulinu štrukäti (RMG 234), u Orlecu, na Braču, na Unijama štrukät (ČDOC 372; RBČG 945; UKS 175), u Belom śtrukät (BBT 470), u Korčuli štrùkat (RGGK-cd) < mlet. strucar (VG 1110), strucàr (BOE 717; DDP 267; DDC 240) < lat. *trŭdícāre, REW 894368. Imenica je nastala unutar istrorumunjskoga sa semantizmom koji ne odgovara u potpunosti samom referentu - obično se cijedi polovica naranče a ne kriška po kriška.

\subsection{Narančina kora}

U Žejanama skorca de narånže, u Šušnjevici kora de narånce, u Novoj Vasi lúupa de narånče, u Jesenoviku, Letaju i Mihelima kora de narånče, u ostalim južnim selima Iupa de narånče.

Za kora69 i skorca v. 14.1., za lupa 14.1. i 1.1., za de 1.2., za narånče 20.

\section{Zaključak}

U obrađenoj građi prevladavaju posuđenice iz čakavskih govora. Domaćih je riječi malo, no za neke se to ne može s potpunom sigurnošću utvrditi jer se u potpunosti, i na planu izraza i na planu sadržaja, poklapaju s čakavskim ekvivalentima - u tim smo slučajevima redovito pretpostavili da je riječ o izvornom obliku koji se (uglavnom) neznatno promijenio (moguće i na oba plana) pod utjecajem čakavskoga (npr. koža - 14.2.). Izravnih posuđenica iz (istro)mletačkoga nema, sve su ušle preko nekog čakavskoga govora, no ni to nije uvijek moguće nedvosmisleno utvrditi.

\footnotetext{
68 "Etimo molto discusso. REW 8943 parte da un lat. parl *trudicare "spingere, premere"; il Prati da una base onomatopeica *trukk-; il DEl (approvato da Doria) dal got. thruks (ted. mod. Druck) "colpo, spinta, pressione"." (DDC 240, s. v. strucàr).

69 Usp. u Brgudu (IrLA 1655), Svetvinčentu i Ližnjanu (ILA 1655) kôra od narânče, u Čepiću (IrLA 1655) köra od narônče.
} 


\section{POPIS LITERATURE}

ADK - Golab, Zbigniew 1984. The Arumanian Dialect of Kruševo in SR Macedonia, SFR Yugos/avia. Skopje: Македонска академија на науките и уметностите.

ARJ - *** 1880.-1976. Rječnik hrvatskoga ili srpskoga jezika, I-XXIII. Zagreb: HAZU (tada JAZU).

BBT - Velčić, Nikola 2003. Besedar Bejske Tramuntane. Mali Lošinj - Beli - Rijeka: Katedra Čakavskog sabora Cres-Lošinj, Tramuntana, Adamić.

BOE - Boerio, Giuseppe 1971. (pretisak mletačkog izdanja iz 1856.). Dizionario del dialetto veneziano. Milano: Martello Editore.

ČDO - Kalsbeek, Janneke 1998. The Čakavian Dialect of Orbanići near Žminj in Istria. Amsterdam - Atlanta: Editions Rodopi B. V.

ČDOC - Houtzagers, Hubrecht Peter 1953. The Cakavian Dialect of Orlec on the Island of Cres, Amsterdam: Rodopi.

DAR - Gh. Bulgăr, Gh. Constantinescu-Dobridor 2000. Dicţionar de arhaisme şi regionalisme, Bukurešt: Editura Saeculum.

DArM - Cuvata, Dina 2006. Dictsionar armãnescu - machidunescu. Skopje: Uniea ti culturã-a Armãnjlor dit Machidunii.

DDAr - Papahagi, Tache 1963. Dicţionarul dialectului aromîn. Bukurešt: Editura Academiei Republicii Populare Romîne.

DDC - Manzini, Giulio - Luciano Rocchi 1995. Dizionario storico fraseologico etimologico del dialetto di Capodistria. Trst, Rovinj: Unione Italiana Fiume, Università Popolare di Trieste.

DDP - Orbanich Pino - Barbara Buršić Giudici 2009. Dizionario del dialetto di Pola. Rovinj:Unione italiana - Fiume, Università popolare - Trieste, Znanstvena udruga MEDITERAN - Pula.

DELI-cd - Cortelazzo, Manlio - Paolo Zolli 1999. Dizionario Etimologico della Lingua Italiana. Bologna: Zanicchelli (izdanje na CD-u).

DER - Cioranescu, Alejandro 1966. Diccionario etimologico rumano. Tenerife - Madrid: Editorial Gredos.
DEX - *** Dicționarul explicativ al limbii române 1998. Bukurešt: Univers Enciclopedic.

DIr - Sârbu, Richard - Vasile Fraţilă 1998. Dialectul istro-român. Temišvar: Editura Amarcord.

DLI-cd - Devoto, Giacomo - Gian Carlo Oli 2002. Dizionario della lingua italiana. Firenze: Le Monnier.

DMr - Capidan, Theodor 1928. Meglenoromâni III: Dicţionar meglenoromân. Bukurešt: Academia Română.

DRI - Popovici, Josif 1909. Dialectele romîne, IX: Dialectele romine din Istria, partea a $2^{A}$ (texte Ei g/osar). Halle A. D. S.: Editura autorului.

ESSJ - Bezlaj, France 1977.- 2007. Etimološki slovar slovenskega jezika (I-V). Ljubljana: SAZU.

EWRS-LE - Puşcariu, Sextil 1905. Etymologisches Wörterbuch de rumänischen Sprache: I. Lateinisches Element, Heidelberg: Carl Winter's Universitätsbuchhandlung.

GDDT - Doria, Mario 1984. Grande dizionario del dialetto triestino. Trst: Edizioni Italo Svevo.

GG - Lukežić, Iva - Sanja Zubčić 2007. Grobnički govor XX. stoljeća (gramatika i rječnik). Rijeka: Katedra Čakavskog sabora Grobinšćine.

HBI - Ivan Šugar 2008. Hrvatski biljni imenoslov, Zagreb: Matica Hrvatska.

HER - Alemko Gluhak 1993. Hrvatski etimološki rječnik. Zagreb: August Cesarec.

ID - Ribarić, Josip 2002. O istarskim dijalektima. Pazin: Josip Turčinović d. o. o.

ILA - Filipi, Goran - Barbara Buršić Giudici 1998: Istriotski lingvistički atlas. Pula: Znanstvena udruga Mediteran.

IrG - Byhan, Arthur 1899. Istrorumänisches Glossar. lahres-bericht des Instituts für rumänische Sprache, IV. Leipzig, str. 174-396.

IrHR - Kovačec, August 1998. Istrorumunjskohrvatski rječnik s gramatikom i tekstovima. Pula: Znanstvena udruga Mediteran. 
IrLA - Filipi, Goran 2002. Istrorumunjski lingvistički atlas / Atlasul Lingvistic Istroromân / Atlante Linguistico Istro-rumeno. Pula: Znanstvena udruga Mediteran.

LVJ - Fortunato, Andro Roki 1977. Libar viškiga jazika. Toronto: vlastita naklada.

MALGI - Radu Flora 2003. Micul Atlas Lingvistic Al Graiurilor Istroromâne. Bukurešt: Editura Academiei Române.

MFR - Selman, Alexander 2006. Mali funtanjanski rječnik. Funtana: vlastita naklada.

MrA - Atanasov, Petar 2002. Meglenoromâna astăzi. Bukurešt: Editura Academiei Române.

MtP-cd - Maks Pleteršnik 2006. Slovesnko-nemški slovar (1894-1895) - transliterirana izdaja, izdanje na CD-u, Ljubljana: SAZU.

PI - Ružić Sudčev, Šime 1999. Pićan i pićònski idiomi. Pula: C.A.S.H.

RBČG - Šimunović, Petar 2009. Rječnik bračk ih čakavskih govora. Zagreb: Golden marketing Tehnička knjiga.

RBG - Francetić, Ivan 195X. Rječnik boljunskih govora. Boljun: (rukopis s konca pedesetih godina 20. st., nalazi se na Odjelu za humanističke znanosti Sveučilišta "Juraj Dobrila" u Puli).

RČGNV - Sokolić - Kozarić, Josip M. - Gojko M. Sokolić - Kozarić 2003. Rječnik čakavskog govora Novog Vinodolskog. Rijeka - Novi Vinodolski: vlastita naklada.

RČGR - Mohorovičić - Maričin, Franjo 2001. Rječnik čakavs-kog govora Rukavca i bliže okolice. Rijeka - Opatija - Matulji: Adamić, Katedra čakavskog sabora Opatija.

RMG - Marija Peruško 2010. Rječnik medulinskoga govora, Medulin: Mendula - Općina Medulin.

REW - Meyer-Lübke, Wilhelm 1972. Romanisches etymologisches Wörterbuch. Heidelberg: Carl Winter, Universitätsverlag.

RGGK-cd - Kalogjera, Damir - Mirjana Svoboda - Višnja Josipović 2008. Rječnik govora grada Korčule. Zagreb: Novi liber (cd izdanje).
RGK - Maričić Kukljičanin, Tomislav 2000. Rječnik govora mjesta Kukljice. Zadar: Matica hrvatska.

RGOM - Juraga, Edo 2010. Rječnik govora otoka Murtera. Murter - Šibenik: Ogranak Matice hrvatske Šibenik, Županijski muzej Šibenik.

RGS - Piasevoli, Ankica 1993. Rječnik govora mjesta Sali. Zadar: Matica hrvatska - Ogranak Matice hrvatske Zadar.

RGV - Jurišić, Blaž 1973. Rječnik govora otoka Vrgade, II. Zagreb JAZU (danas HAZU).

$\mathrm{RHJ}$ - *** 2000. Rječnik hrvatskoga jezika, Zagreb: Školska knjiga.

RKGP - Ivo Oštarić 2005. Rječnik kolanjskoga govora ili Ričnik mista Kolana na otoku Pagu, Zadar: Matica hrvatska.

RLC - Milevoj, Marijan 2006. Gonan po nase (rječnik labinske cakavice). Labin: Mathias Flacius.

RMG - Peruško, Marija 2010. Rječnik medulinskoga govora. Medulin: Mendula, Općina Medulin.

RR - Kalčić, Slavko 1999. Roverski rječnik (rukopis).

RRG - Radulić, Ladislav 2002. Rječnik rivanjskog govora. Zadar: Matica hrvatska.

RVG - Blaž Jurišić 1973. Rječnik govora otoka Vrgade. Zagreb: JAZU.

SES - Snoj,Marko 1997. Slovenski etimološki slovar. Ljubljana: Založba Mladinska knjiga.

SIr - Puşcariu, Sextil 1929. Studii istroromâne, III. Bukurešt: Cultura Naţională.

SKOK - Skok, Petar 1971.-1974. Etimologijski rječnik hrvatskoga ili srpskoga jezika, I-IV. Zagreb: JAZU (danas HAZU).

SR - Moguš, Milan 2002. Senjski rječnik. Zagreb Senj: HAZU, MH Senj.

SSKJ-cd - *** 2005. Slovar slovenskega knjižnega jezika. Ljubljana: SAZU, DZS (izdanje na CD-u).

StR - Petrić, Željko 2008. Splitski rječnik. Split: Naklada Bošković. 
TIr - Cantemir, Traian 1959. Texte istroromîne. Bukurešt: Editura Academiei Republicii Populare Romîne.

UKS - Margita Nikolić 2000. Unije: kuželj vaf sarcu. Mali Lošinj: Katedra Čkavskog sabora Cres-Lošinj.

VG - Rosamani, Enrico 1999. Vocabolario giuliano. Trst: LINT.

VIr - Maiorescu, Ioan 1996. Itinerario in Istria e vocabolario istriano-romeno. Trst: Edizioni Parnaso.

VIrl-

VIrR - Maiorescu, loan 1900. Itinerar in Istria şi vocabular istriano-român. Bukurešt: Ediţia a doua publicată de Titu Maiorescu.

\section{ETIMOLOGIE ISTRORUMENE RIGUAR- DANTI IL LESSICO CONNESSO AGLI AL- BERI FRUTTIFERI}

Nel presente lavoro viene elaborata la terminologia istrorumena che riguarda le parole connesse con il concetto di albero da frutta. I vocaboli presentati ed elaborati sono stati raccolti durante le interviste per l'IrLA con le verifiche successive. Accanto alle forme raccolte si riportano anche quelle segnate nei repertori istrorumeni a noi disponibili. Ogni espressione viene paragonata alle forme simili nelle parlate ciacave e/o (istro)venete vicine. Le voci appartenenti al corpus rumeno, si paragonano con le forme degli altri tre dialetti rumeni (dacorumeno, arumeno e meglenorumeno). La maggior parte del lessico in questione rappresenta i prestiti dai dialetti croati ciacavi, e solo pochissime parole appartengono allo strato nostrano della parlata istrorumena - bisogna però sottolineare che alcuni di questi lessemi non possono essere definiti come nostrani con assoluta certezza, per il fatto che coincidono perfettamente (sul piano semantico e quello formale) alle parole ciacave corrispondenti. Prestiti diretti dal(l')(istro)veneto non si riscontrano.

Parole chiave: istrorumeno, rumeno, croato, ciacavo, dialettologia, etimologia 